\title{
Türk-Yunan İlişkileri Kapsamında Kıta Sahanlığı Uyuşmazlığının Çözüm Yeri Birleşmiş Milletler Uluslararası Adalet Divanı Olabilir mi?
}

\author{
Can the United Nations International Court of Justice be the Solution \\ Place for the Continental Shelf Dispute Within the Scope of Turkish- \\ Greek Relations?
}

\author{
Hakkı Hakan Erkiner* iD, Mehmet Emin Büyük ${ }^{* *}$ iD
}

\section{öz}

Ege Denizi üzerindeki kıta sahanlığı sınırlandırması meselesi, Türkiye ve Yunanistan arasında çözüm bekleyen uyuşmazlıklardan biridir. Özellikle 70’li yıllardan itibaren görünürlük kazanan bu sorun, Yunanistan’ın tek taraflı başvurusu ertesinde Uluslararası Adalet Divanı’nın 1978 tarihli yetkisizlik kararılla birlikte bütünüyle siyaset ve diplomasi sorunu haline gelmiştir. Öte yandan birçok devletin benzer sınırlandırma sorunları yaşadığı ve bunları Divan veya farklı uluslararası yargı organları eliyle çözüme kavuşturma çabası içine girdiği görülmektedir. Bunun sonucunda yargı organlarının deniz alanlarının sınırlandırılması meselesine dair ciddi bir içtihadi birikimi ortaya çıkmıştır. Deniz alanlarının sınırlandırılması hukukunda baskın ilke, sınırlandırmanın hakça bir çözüme kavuşturacak şekilde yapılmasıdır. Bu düşünce, 1982 Birleşmiş Milletler Deniz Hukuku Sözleşmesi’ne de girmiştir. Bu bakımdan Ege Denizi’nde yapılacak bir sınırlandırmada, en doğudaki Yunan adaları ile Türkiye anakarası arasında çizilecek bir eşit uzaklık çizgisine dayalı bir sınırlandırma yapılmasının hakça olmaması sebebiyle, yargı organlarından bu yönde bir karar çıkmayacağı beklenebilir. Öte yandan bu çalışmanın ortaya koyduğu görüş, her ne kadar Divan'dan çıkacak kararın içtihat ışığında, Türkiye tezleri lehine bir sonuç getirebileceği düşünülse de bu karar bir kez verildikten sonra dönüşün olmayacağı bilinmeli, uyuşmazlığın diplomasi ve 1982 Sözleşmesi’ndeki öncelikli usul olan anlaşma yoluyla çözülmesi yönündeki çabalar sürdürülmelidir.

Anahtar Kelimeler: Kıta Sahanlığı Sınırlandırması Uyuşmazlığı, Ege Denizi, Ege Sorunu, Uluslararası Adalet Divanı, Deniz Alanlarının Sınırlandırılması, İçtihat Hukuku

* Doç. Dr. , Marmara Üniversitesi Hukuk Fakültesi Milletlerarası Hukuk Anabilim Dalı, ORCID: 0000-0002-0779-6414

** Arş. Gör., Marmara Üniversitesi Hukuk Fakültesi Milletlerarası Hukuk Anabilim Dalı, ORCID: 0000-0002-7392-4488

Sorumlu Yazar/Correspondence Author: Hakkı Hakan Erkiner

E-posta/E-mail: herkiner@marmara.edu.tr

Geliş Tarihi/Received: $\quad$ 01.09.2021 Kabul Tarihi/Accepted: $\quad 25.09 .2021$ 


\section{ABSTRACT}

The issue of the continental shelf delimitation on the Aegean Sea is one of the disputes pending between Turkey and Greece. This problem, which has gained visibility especially since the 70s, has become a purely political and diplomatic problem with the 1978 decision of the International Court of Justice, following the unilateral application of Greece. On the other hand, it is seen that many states have similar limitation problems and try to resolve them through the Court or different international judicial bodies. As a result, a serious accumulation of jurisprudence (case-law) has emerged on the issue of the delimitation of maritime areas by the judicial bodies. The predominant principle in the law of delimitation of maritime areas is that the delimitation should be done in a way that provides an equitable solution. This idea was also included in the 1982 United Nations Convention on the Law of the Sea. In this respect, since it would not be fair to make a delimitation based on an equidistance line to be drawn between the easternmost Greek islands and the Turkish mainland, it can be expected that a decision in this direction will not be made by the judicial organs. On the other hand, the view put forth by this study is that although it is thought that the decision of the Court may bring a result in favor of the Turkish theses in the light of case law, it should be known that once this decision is made, there will be no turning back and that the efforts to resolve this conflict through diplomacy and agreement which is the primary procedure in the 1982 Convention, should continue.

Keywords: Dispute of Continental Shelf Delimitation, Aegean Sea, Aegean Dispute, The International Court of Justice, Maritime Delimitation, Case-Law

\section{GiRiş}

Türkiye ve Yunanistan arasında çözüm bekleyen birden fazla sorundan bahsetmek mümkündür. Ege Denizi üzerinde karasuları, kıta sahanlığı, muhtemel bir gelecekte gündeme gelebilecek olan münhasır ekonomik bölge sorunu, adaların aidiyeti ve silahsızlandırılmasına ilişkin sorunlar, Doğu Akdeniz üzerinde münhasır ekonomik bölge ve ilintili olarak kıta sahanlığı sorunu gibi farklı başlıklar altında özetlenebilecek bu sorunların ve özelde bu çalışmada ele alınan kıta sahanlığı sorununun Uluslararası Adalet Divanı veya bir tahkim mahkemesi eliyle çözülmesi dönem dönem gündeme getirilmektedir. Bu çalışmada, Ege Kıta Sahanlığı sorununa ilişkin tarihsel süreç hatırlatıldıktan sonra, deniz alanlarına ilişkin uyuşmazlıklar bakımından mahkemelerin yargı yetkisi meselesi incelenecek, deniz alanlarının sınırlandırılmasına ilişkin içtihat hukukuna dair bilgiler verilecek ve bu bilgiler 1şı̆̆ında Ege Denizi üzerinde var olan kıta sahanlığı uyuşmazlığına dair olası bir yargılamada ne gibi sonuçlar çıkabileceğine dair öngörüler ifade edilecektir. Son olarak, uluslararası hukukta Lahey Divanı tarafından verilen yargı kararlarının uygulanması hususu açıklanacak ve çalışmanın ele aldığ 1 konularla ilişkilendirilecektir.

70'li yıllarda görünürlük kazanan Ege Denizi Kita Sahanlığı Uyuşmazlığı, büyük oranda diplomasinin konusu olmuştur. Dönemsel olarak taraflar arasında olası bir savaş sebebi haline gelen bu sorun, genelde ikili ilişkiler ve diplomasi yoluyla çözüme kavuşturulmaya çalışılmış ancak günümüze kadar bir çözüm bulunamamıştır. Bu süreçte, Yunanistan tarafından Uluslararası Adalet Divanı’na yapılan başvuru, 1978 tarihli kararla yetkisizlik sebebiyle reddedilmiştir. Bu sorunun zaman içinde Avrupa Birliği ve Türkiye arasındaki ilişkilere yansıyan bir soruna dönüştüğü de ifade edilmelidir. 
Uluslararası hukukta devletler üstü bir otorite bulunmadığı gibi, devletlerin tarafı oldukları bir uyuşmazlığı yargı organları önüne götürmeleri konusunda zorlanmaları da mümkün değildir. ${ }^{1}$ Devletlerin yargı organlarının yetkisini çeşitli yöntemlerle kabul etmeleri mümkün olabilir. Türkiye 1982 Birleşmiş Milletler Deniz Hukuku Sözleşmesi’ne taraf olmadığ 1 için burada öngörülen uyuşmazlık çözüm yöntemlerine de tabi değildir. Aynı şekilde, Ege kıta sahanlı̆̆ı sorunu açısından Uluslararası Adalet Divanı’nın yargı yetkisini kabul eden bir fiili bulunmamaktadır. Türkiye, istediği zaman bu sorunun Divan tarafından çözülmesi hususunda rıza açıklamasında bulunabilir.

1969 tarihli Kuzey Denizi Kıta Sahanlığı Davası’ndan itibaren yargı kararlarıyla şekillenen bir deniz alanları sınırlandırması hukukundan bahsetmek mümkündür. Bu davadaki görüşlerin 1982 Sözleşmesi’nde de yer aldığını ifade etmek gerekir. Deniz alanlarının sınırlandırılmasında içtihat hukuku, hakça ilkeler temelli ancak zaman içinde soyutluktan arındırılmış birtakım yöntemlere doğru gelişim göstermiştir.

Uluslararası Adalet Divanı tarafından verilen kararlar kesindir. Birleşmiş Milletler Andlaşması da, andlaşmanın tarafı devletlerin Divan’n kararına uymakla yükümlü olduklarını düzenlemektedir. Duruma göre, Divan kararlarının uygulanması için Güvenlik Konseyi tarafından tedbirler alınabilir. Hakça ilkeler tezinin ve birçok yönüyle içtihadın Türkiye’nin görüşleri lehine olduğu açıktır. Bu bakımdan Uluslararası Adalet Divanı́na Ege kıta sahanlı̆̆ı sorununun götürülmesi durumunda hakça bir çözüm beklenmesi mümkündür. Ancak özellikle sınırlandırmaya esas alınacak esas hatların nereden başlatılacağı gibi sorunlarda bütünüyle bir öngörülebilirlikten bahsetmek zordur.

$\mathrm{Bu}$ çalışmada, dört ayrı başlık kapsamında yukarıda özetlenen hususlara dair ayrıntılara yer verilerek çalışmanın ana fikri için zemin hazırlanacaktır: (1) Uyuşmazlığın tarihçesi, (2) yargı organlarının yetki meselesi, (3) deniz alanları uyuşmazlıklarında içtihat hukukunun seyri ve Ege sorunu bakımından öngörüler ve son olarak (4) Divan kararlarının niteliği ve uygulanması. Böylece ulaşılacak sonuç tek cümle ile ifade edilecek olursa; her ne kadar Divan'dan çıkacak kararın içtihat ışığında, Türkiye tezleri lehine bir sonuç getirebileceği düşünülse de bu karar bir kez verildikten sonra dönüşün olmayacağı bilinmeli, uyuşmazlı̆̆ın, 70'li yıllardan bugüne olduğu gibi, diplomasi ve 1982 Sözleşmesi’ndeki öncelikli usul olan anlaşma yoluyla çözülmesi yönündeki çabalar sürdürülmelidir.

\section{UYUŞMAZLIĞA ILIŞKIN TARIHSEL GELIŞiM VE TARAFLARIN HUKUKi GÖRÜŞLERi}

\section{A. UYUŞMAZLIĞIN ORTAYA ÇIKIŞI}

Yunanistan, 1960'lı yllarda o dönemin bilinen birtakım petrol şirketlerine Ege Denizi’nin çeşitli yerlerinde petrol ve çeşitli madenlerin keşfine dair ruhsatlar vermeye başlamıştır. Türkiye ise, bu girişimlere karşı 1973 yılında Türkiye Petrolleri Anonim Ortaklığı̉na, Yunanistanın kendi kıta sahanlığı olduğunu iddia ettiği Ege Denizi’ndeki açık deniz alanlarında 27 adet petrol arama faaliyeti

Hakkı Hakan Erkiner, 'Uluslararası Topluluk Kavramı' (2010) 16(1-2) MÜHF-HAD 67; Hakkı Hakan Erkiner, 'Uluslararası Topluluk Kavramının Başlıca Görünümleri' (2010) 16(1-2) MÜHF-HAD 88. 
konusunda ruhsat vermiştir. Söz konusu bölgeler, Limni, Midilli, Sakız ve Semendirek gibi Yunan adalarının 6 mil karasularının hemen dışında kalan açık deniz alanlarıdır. Yunan tarafı, bu deniz alanlarının 1958 Cenevre Kıta Sahanlığı Sözleşmesi uyarınca kendisinin kıta sahanlığı içerisinde yer aldıklarını ve egemen haklarının saklı olduğunu ifade eden 7 Şubat 1974 tarihli bir nota göndermiştir ve 1974 ve 1975 yıllarında karşılıklı protestolar içeren bir dizi nota teatisi iki devlet arasında sürdürülmüştür. 1975 yllına gelindiğinde, taraflar bu uyuşmazlığın Uluslararası Adalet Divanı’na götürülmesine dair bir tahkimname hazırlanması ve gerekli teknik meselelerin çözülmesine dair müzakerelere girişmişlerdir. İki devletin dışişleri bakanları bu amaçla 17-19 Mayıs 1975’te Roma’da birtakım görüşmelerde bulunmuştur. Bu toplantılardan kısa bir süre sonra NATO Zirvesi için bir araya gelen iki devlet Başbakanı Demirel ve Karamanlis, 31 Mayıs 1975 tarihli Brüksel Bildirisìni açıklamışlardır. Söz konusu bildiride iki devlet arasındaki sorunların barış içinde "görüşmeler yoluyla ve Ege Denizi kıta sahanlı̆̆ sorununun ise Lahey'deki Milletlerarası Mahkeme tarafindan çözümlenmesi gerektiğini kararlaştırdıkları" vurgulanmış ve yine bu amaçla "kıta sahanlı̆̆ı sorunuyla ilgili olduğu gibi hava sahası sorunuyla da ilgili olarak teknik heyetlerin toplantı tarihini öne almayı kararlaştırdiklari" açıklanmıştır. ${ }^{2}$

\section{B. ULUSLARARASI ADALET DIVANI - EGE DENIZI KITA SAHANLIĞI DAVASI ${ }^{3}$}

İki devlet arasında daha sonra yapılan bir dizi görüşmede anlaşmaya varılamamıştır. Bunun üzerine Türkiye, MTA Sismik I araştırma gemisini, Yunan karasuları dışında kalan Ege Denizi açık deniz alanlarında deniz tabanında araştırmalar yapması için görevlendirdiğini ilan etmesi üzerine, Yunanistan, bu deniz alanlarının kendi kıta sahanlığı alanları olduğunu ileri sürerek, uyuşmazlığı 7 Ağustos 1976 tarihli dilekçesiyle tek taraflı olarak Uluslararası Adalet Divanı́na sunmuş ve yine aynı şekilde 10 Ağustos tarihli bir dilekçeyle de tek taraflı olarak konuyu Birleşmiş Milletler Güvenlik Konseyỉnin gündemine taşımıştır. ${ }^{4}$

Yunanistan, BM Güvenlik Konseyỉne başvurusunu, Türkiye’nin yaptığı araştırmaların kendi kıta sahanlığında olması hasebiyle uluslararası barış ve güvenliği tehdit ettiği argümanına dayandırmıştır. Güvenlik Konseyi 25.8.1976 tarih ve 395 (1976) sayllı kararında taraflara görüşmelere yeniden başlama ve uygun yargı usullerinin, bilhassa Uluslararası Adalet Divanı'na meselesinin taşınmasının çözüme katkı sunacağı konusundaki görüşlerini taraflara bildirmiştir. ${ }^{5}$

Yunanistan’ın Uluslararası Adalet Divanı başvurusu, Türkiye’nin arama ruhsatı verdiği alanlarda dava sonuçlanana kadar herhangi bir araştırma faaliyetinde bulunmaması yönünde bir ihtiyati tedbir kararı vermesi talebini de içermektedir. Davanın esasına ilişkin olarak da Divan’dan, Yunan adaları

2 Sevin Toluner, Milletlerarası Hukuk Dersleri - Devletin Yetkisi (4. Baskı, Beta 1989) 248-249. Ayrıca bkz. Aslan Gündüz, 'Discord Between Greece and Turkey over the Extent of Their Continental Shelves in the Aegean' (1996) 4(2) Hellenic Studies 96-97; Angelos Syrigos ve Thanos Dokos, Atlas of Greek-Turkish Relations (Kathimerini 2020$) 46$.

3 Aegean Sea Continental Shelf (Greece v. Turkey), Judgment (ICJ Reports 1978).

4 Selami Kuran, Uluslararası Deniz Hukuku (6. Baskı, Beta 2020) 240; Toluner (n 2) 249-250.

5 Hüseyin Pazarcı, Uluslararası Hukuk Dersleri - 2. Kitap (9. Baskı, Turhan Kitabevi 2013) 376-377. 
ve Türkiye arasında kıta sahanlığı sınırlandırmasının ne şekilde yapılacağının belirlenmesi talep edilmiştir.

Uluslararası Adalet Divanı, başvuruya ilişkin olarak, bir yandan görüşünü almak üzere Türkiye’yi bilgilendirmiş, diğer yandan da ihtiyati tedbir talebini öncelikli olarak incelemeye almıştır. Divan’n 11 Eylül 1976 tarihli kararında, Türkiye tarafından yapılmakta olan araştırmaların deniz yatağına veya buradaki canlı varlıklara zarar veren bir nitelikte olmadığı ve tarafların lehine veya aleyhine bir hak kazancı veya kaybı ortaya çıkarmayacağı gerekçesiyle, giderilmesi imkansız bir zararın verilmesi durumu söz konusu olmadığına ve dolayısıyla bir ihtiyati tedbir kararına ihtiyaç bulunmadığına hükmetmiştir. ${ }^{6}$

Türkiye, Yunanistan tarafından açılan bu davada başından itibaren yetkisizlik itirazında bulunmuş ve ad hoc yargıç atama yoluna da gitmemiştir. Divan, yetkiye ilişkin incelemelerine geçmeden önce, Türkiye’nin sunduğu birtakım ön itirazları karara bağlamış ve bunların tümünü reddetmiştir. Buna göre, 1) taraflar arasında müzakerelerin devam ediyor olması Divan önünde bir davanın görülmesine engel oluşturmaz; 2) halihazırda müzakerelerin devam ediyor olması "uyuşmazlığın varlığı"nı etkileyen bir husus değildir; 3) meselenin siyasi yönleri olsa da, Divan tarafından incelenebilecek bir "hukuki sorun" olayda mevcuttur. ${ }^{7}$

Yunanistan’n Divan’n yetkisine ilişkin iki temel dayanak ileri sürdügü görülmektedir. Bunlardan ilki, Uluslararası Adalet Divanı Statüsü’nün 36/1 ve 37. maddeleri bağlamında 1928 tarihli Uluslararası Uyuşmazlıkların Barışçı Yollarla Çözümüne Dair Genel Senedin 17. maddesidir. Yetkiye dair ikinci dayanağı ise, yukarıda da bahsi geçen, 1975 tarihli Brüksel ortak bildirisidir.

1928 tarihli Genel Senedin 17. maddesi, sözleşmenin tarafları arasındaki uyuşmazlıkların, çekincelere dair 39. madde hükümleri saklı kalmak üzere, Uluslararası Daimi Adalet Divanı önünde çözümlenmesini öngörmektedir. Türkiye bahsi geçen Genel Senedin yürürlükte olmadığını, olsa bile Yunanistan’ın “ülke statüsü”ne ilişkin ihtilafların Divan’n yargı yetkisi dışında kalacağına dair çekincesi nedeniyle Divan’n yargı yetkisinin bulunmadığını iddia etmiştir. Divan, daha önce de Nükleer Denemeler Davası'nda gündeme gelmiş olan Genel Senedin yürürlükte olup olmadığı tartışmalarına bu davada da girmemiş ancak kararını Yunanistan’n ilgili sözleşmeye koyduğu çekinceye dayandırarak vermiştir. Sonuç olarak Divan, Yunanistan’ın kıta sahanlığı meselelerinin ülkesel statüye ilişkin ihtilaflar kapsamında olmadığı argümanını reddetmiştir. ${ }^{8}$

Yunanistanın yetkiye ilişkin öne sürdüğü diğer husus olan Brüksel Ortak Bildirisìnin de yine aynı şekilde Divan’n davaya bakma yetkisi konusunda geçerli bir temel oluşturmadığı kanaatine varılmıştır. Divan’a göre bu tür bir ortak bildirinin andlaşma olarak kabul edilmesi önünde herhangi bir engel bulunmaz. Ancak diğer yandan bahsi geçen ortak bildirinin içeriğine ilişkin taraflar arasındaki uzlaşma ve ilgili şartlar göz önüne alındığında, açıklanan bildirinin niyetinin uyuşmazlığın

6 Toluner (n 2) 250-251.

7 Karin Oellers-Frahm, 'Aegean Sea Continental Shelf Case' in Rudolf Bernhardt (ed), 2 Encyclopedia of Public International Law (North Holland, Elsevier 1981) 6.

8 Oellers-Frahm (n 7) 6; Toluner (n 2) 251-252. 
derhal Divan’a sunulmasına yönelik olmadığı anlaşılmaktadır. Dolayısıyla bu bildiriyle ortaya çıkan bir yargı yetkisinin varlı̆̆ından söz edilemez. ${ }^{9}$

Sonuç olarak Divan, 19 Aralık 1978 tarihinde, Yunanistan’n tek taraflı başvurusu ile açılmış olan Ege Denizi kıta sahanlığının sınırlandırılmasına ilişkin davada 12 oya karşı 2 oyla yargı yetkisinin bulunmadığına hükmetmiş ve başvuruyu reddetmiştir.

\section{DIVAN KARARI SONRASI SÜREÇ}

BM Güvenlik Konseyi kararı ve Divan’n geçici önlemler alınması gerekliliğinin olmadığına dair kararı sonrasında iki devlet arasındaki gerginlikler yeni bir aşamaya geçmiştir ve müzakerelerin yeniden başladığı bir döneme girilmiştir. 1 Ekim 1976'da iki devletin dışişleri bakanları (Bitsios ve Çağlayangil) New York’ta bir araya gelmiş ve kıta sahanlığ sorunlarının çözümüne ilişkin bir ilke belirlenmesi hususunda toplantılara başlanması konusunda anlaşmışlardır. 2-11 Kasım 1976 tarihinde Bern'de yapılan toplantılarda ilkeleri saptayan 11 Kasım 1976 tarihli Bern Anlaşması yapılmış ve "kıta sahanlığının sınırlandırılmasında karşıllklı rızalara dayanarak oluşturulacak bir anlaşmanın sağlanabilmesi için samimi, ayrıtıth ve güven içerisinde bir yaklaşım izlemeyi, yapılacak olan görüşmelerin içeriğinden dolayı gizli tutulmasını kararlaştırmışlardır." Yine yapılan anlaşma gereğince, tarafların bu toplantılar esnasında ifade ettiği görüşlerin uyuşmazlığa ilişkin hususlar bakımından görüş değişikliği olarak kabul edilmemesi ve görüşmelerin kapsamı dışında kullanılmaması konularında uzlaşılmıştır. Ayrıca taraflar Ege Denizi kıta sahanlığı ile ilgili olarak yapılan müzakerelere zarar verebilecek girişimlerden kaçınma yükümlülüğü ile birlikte, ikili ilişkilerle ilgili olduğu kadar, diğer tarafı güvensizliğe itebilecek herhangi bir inisiyatif ya da davranıştan kaçınmayı da kararlaştırmışlardır. Bu hususların yanında, kıta sahanlığı sınırlandırılması konusunda göz önünde bulundurulacak temel ilkeler ve ilgili kriterleri belirlemek amacıyla, uluslararası hukuk ve örf ve adet kurallarının araştırılması konusunda uzlaşılmış ve buna yönelik, iki devletin temsilcilerinden oluşan bir karma komisyonun kurulması kararlaştırılmıştır. ${ }^{10}$

Bern Anlaşması sonrasında iki devlet başbakanları (Ecevit ve Karamanlis), 1978 yılı içerisinde Montreux'de ve Washington'da bir araya gelmişler ve görüşmelerin karşllıklı güven içerisinde sürdürülmesi hususunda anlaşmışlardır. Buradaki uzlaşmaya uygun olarak 1978-79 yılları içerisinde Dışişleri Genel Sekreterleri ve çeşitli uzmanlar düzeyinde bir dizi görüşme gerçekleştirilmiştir. ${ }^{11}$

Yunanistan ve Türkiye’nin kıta sahanlığı meselesine dair yorumlarındaki farklılık, 5 Ekim 1980 tarihinde New York’ta bir araya gelen Türk Dışişleri Bakanı İlter Türkmen ile Yunan Dışişleri Bakanı Konstantinos Mitsotakis arasında geçen görüşmelerde net bir şekilde ortaya çıkmaktadır. Gürün'ün aktardığına göre, bu toplantı sırasında Mitsotakis, "Kita sahanlı̆̆ konusunda bunun siyasi olmaktan çok, hukukî bir sorun olduğunu belirtmekle yetineceğim. Kita sahanlı̆ı̆ın sinırlandırlması kadar, kaynaklarm müştereken işletilmesi meselesine bir hal şekli bulunmasın oldukça güç görüyorum. Bunun

9 Oellers-Frahm (n 7) 6-7; Toluner (n 2) 252-253.

10 Toluner (n 2) 254-255.

11 Ibid 255. 
için, hakkaniyeti içeren milletlerarası hukuka atıf yapmak zorunluluğundayız. Eğer, prensiplerde anlaşamaz ve ikili görüşmelerden de sonuç alamazsak, milletlerarası tahkim yoluna başvurmak zorunluluk olacaktır. İki tarafın da bu alandaki hassasiyeti malum olduğuna göre, tahkim yolu en sağlkklı yol olacaktır." demiştir. İlter Türkmen ise, buna karşıllk olarak, "Kıta sahanlı̆̆ı siyasal bir konudur. Bu itibarla biz, karşıllkl görüşmeyi tercih ediyoruz. Halen de başka bir forumu düşünmüyoruz. İkili görüşmeleri yürüten müzakerecilere güvenmeye devam etmeliyiz." demiştir. ${ }^{12}$

1980 yılında NATO’nun askeri kanadına Yunanistan’’n dönüşü konusunda Türkiye’nin tavrına rağmen bu dönemde ikili ilişkilerin kötüye gittiği görülmektedir. Özellikle de 1981 seçimlerinde, Yunanistan'da PASOK lideri Papandreu'nun iktidara gelmesi, ilişkilerin daha da kötüye gitmesine sebep olmuştur. 1982 Birleşmiş Milletler Deniz Hukuku Sözleşmesi’nin kabulüyle birlikte Yunanistanın karasularını 12 deniz miline çıarma arzusu ve buna karşılık Türkiye’nin bunu bir savaş sebebi sayması da gerginliği tırmandırmıştır. Bu dönemde yaşanan bir diğer olay da 1987 yılında Yunanistan’ın Bern Anlaşmasından doğan yükümlülüklerini geçersiz sayarak, Ege Denizinde yeniden petrol arama faaliyetlerinde bulunacağını açılaması olmuştur. Bunun üzerine Türkiye de, TPAO'ya petrol arama ruhsatı verilmesine ilişkin süreci başlatmış ve Ege Denizi yeniden bir sıcak çatışma potansiyeli taşıyan bir deniz alanı durumuna evrilmiştir. 1987 krizi, Başbakanların karşılıklı iyi niyet açılamalarıla çözüme kavuşturulmuştur. ${ }^{13}$

Yunanistanın, 1981 yllında Avrupa Birliği (o zamanki adıyla Avrupa Topluluğu)'ne üye olmasıyla birlikte, Ege Denizỉne ilişkin sorunlar yeni bir boyut kazanmıştır. Bu durumun yansımalarına 17 Aralık 2004 tarihli AB Zirvesi Sonuç Bildirisinde yer verilmiş; yine aynı şekilde 3 Ekim 2005 tarihli Müzakere Çerçeve Belgesinde de bu sorunun çözümü Türkiye’nin üyeliği yolunda bir ön şart haline getirilmiştir. Ayrıca, 5-16 Haziran 2006 tarihinde Brüksel'de gerçekleştirilen Avrupa Konseyi Başkanlık Zirvesi Sonuç Bildirgesỉnin Türkiye paragrafında iyi komşuluk ilişkilerinin Kopenhag kriterlerinin bir gereği olduğu ve sorunun çözümünü engelleyen faaliyetlerden kaçınılması gerekliliği ifade edilmiştir. ${ }^{14}$

\section{TARAFLARIN HUKUKI GÖRÜŞLERI}

Ege Denizi üzerinde kıta sahanlığı konusunda uyuşmazlığa ilişkin tarafların hukuki yaklaşımları, o dönemde kabul gören uluslararası hukuk düzenlemelerine göre ortaya çıkmış ve gelişmelere göre de değişim göstermiştir. Bu bakımdan öncelikle, 1970'li yıllarda deniz hukukunda kıta sahanlığını düzenleyen sözleşmenin 1958 Cenevre Kıta Sahanlığı Sözleşmesi olduğunu hatırlatmak gerekir. Türkiye bu sözleşmeyi imzalamamıştır. Buna karşılık Yunanistan, sözleşmenin imzacıları arasındadır. 1958 Sözleşmesi, kıyıları karşılıklı veya bitişik olan devletler açısından kıta sahanlı̆̆ sınırlandırmasının öncelikle anlaşma yoluyla olmasını; anlaşmanın olmadığı ve özel şartların haklı

12 Kamuran Gürün, Firtınalı Yillar (Ad Yayıncllk 1995) 197’den aktaran: Fuat Aksu, Türk-Yunan İlişkileri: İlişkilerin Yönelimini Etkileyen Faktörler Üzerine Bir İnceleme (SAEMK Yayınları 2001), http://www.turkishgreek.org/ikili-iliskiler/ uyusmazliklar/ege-denizi-ne-iliskin-uyusmazliklar/k-ta-sahanl-g-soru-nu (Erişim Tarihi: 31.05.2021).

13 Nurser Gökdemir Işık, Kıta Sahanlı̆̆ı, Hukuki Rejimi ve Ege Sorunu (Doktora Tezi - 9 Eylül Üniversitesi 2006) 189-191.

14 Ibid 193-194. 
kılmadığ ${ }_{1}$ durumlarda ise ortay hat metoduyla sınırlandırmanın belirlenmesini öngörmektedir. ${ }^{15} 3$. Deniz Hukuku Konferansı'nda kabul edilen 1982 Birleşmiş Milletler Deniz Hukuku Sözleşmesi’nde ise, 1969 Kuzey Denizi Kıta Sahanlığı Davası'nın da etkisiyle, kıta sahanlı̆̆ı sınırlandırmasının “hakça bir çözüm bulmak üzere, Milletlerarası Adalet Divanı Statüsünün 38. maddesinde zikredilen milletlerarası hukuka göre anlaşma ile gerçekleştirileceği” ifade edilmiştir. ${ }^{16}$

Tarafların görüşleri özetlenecek olursa;

Yunanistan, Ege Denizi üzerinde kıta sahanlığı olarak kabul ettiği alanlarda Türkiye’nin TPAO’ya verdiği petrol arama ruhsatlarına başından itibaren karşı çıkmaktadır. Zira Yunanistan’a göre, adaların da anakaralar gibi kıta sahanlığı bulunmaktadır. Bu bakımdan Türkiye’nin bu adaların varlığını göz ardı ettiğini öne sürmektedir. Buradan hareketle, sınırlandırma yapılırken eşit uzaklık - ortay hat esaslarına göre sınırlandırma yapılmalı ve bu karşılıklı anakaralardan değil, en doğudaki Yunan adalarıyla Türkiye anakarası arasında yapılmalıdır.

Türkiye, her iki deniz hukuku sözleşmesinde de vurgulanan, sınırlandırmanın anlaşma ile yapılması hususunu öncelemektedir. Eşit uzaklık - ortay hat yöntemi kullanılacak doğru yöntem değildir. Yine Türkiye’nin belli bir döneme kadar Ege Denizi’nde kıta sahanlığı bölgelerinin Anadolu kıtasının doğal uzantısı olduğu tezini savunduğu görülmektedir. Öte yandan, uluslararası hukukta her adanın kıta sahanlığ́ olması gibi bir kural mevcut değildir. Adaların niteliği ve ilgili deniz alanının özel durumu göz önünde bulundurulmalıdır. Özellikle de sınırlandırmanın hem Divan’ın yargılamalarında yerleşmiş olan hem de 1982 Sözleşmesine girmiş olan hakça ilkelere göre yapılması gerekir. ${ }^{17}$

\section{DENIZ ALANLARININ SINIRLANDIRILMASI UYUŞMAZLIKLARININ ULUSLARARASI YARGI ORGANLARINA TAŞINMASINA ILIŞKIN HUSUSLAR}

Uluslararası hukuk, en sade tanımıyla, devletler arasındaki ilişkileri ele alır. Bu hukuk sisteminde iç hukuklardan farklı olarak hiyerarşik bir üst otorite bulunmaz; devletler, eşit egemen süjelerdir. Klasik uluslararası hukuk bu yapı üzerine inşa edilmiştir ve günümüzde de ana hatlarıyla bu yapı sürdürülmektedir. ${ }^{18}$

Uluslararası hukukun bu doğası, uyuşmazlık çözüm yöntemleri konusunda da iç hukuklardan farklı bir modelin ortaya konulmasını zorunlu kılar. İç hukuklarda uyuşmazlık çözümleri devlet otoritesi altında, gerektiğinde rızaya dayanmayan ve sonucunda yaptırımlarla desteklenen bir görünüm arz eder. Buna karşılık uluslararası hukukta ise eşit egemen yapılar olarak devletler, uyuşmazlıklarını bir tahkim veya yargı organı önüne götürmek konusunda serbesttirler; bu konuda zorlanmaları mümkün değildir. ${ }^{19}$

15 Bkz. 1958 Cenevre Kıta Sahanlığı Sözleşmesi, md. 6, Selami Kuran, Derya Aydın Okur, Reşat Volkan Günel, Meltem Sarıbeyoğlu, Uluslararası Hukuk Temel Metinler (3. Baskı, Beta 2014) 337.

16 Bkz. 1982 Birleșmiș Milletler Deniz Hukuku Sözleșmesi, md. 83, Ibid 388.

17 Kuran (n 4) 241-249; karşılaştırmak için bkz. Syrigos and Dokos (n 2) 52.

18 Hakkı Hakan Erkiner, Devletin Haksız Fiilden Kaynaklanan Uluslararası Sorumluluğu (On İki Levha 2010$) 65$.

19 Ibid 62. 
Devletlerin egemenliklerinin uzantısı olarak, diğer devletlerle uluslararası sözleşmeler yapması mümkündür. $\mathrm{Bu}$ sözleşmeler sonucunda devletler birtakım yükümlülükler altına girer ve bu yükümlülüklerin ihlali, o devletin uluslararası hukuk bakımından sorumluluğunu doğurur. ${ }^{20}$ Ancak devletin bir andlaşma ile böyle bir yükümlülük altına girmiş olması, egemenlikten vazgeçilmesi anlamına gelmez. Uluslararası Daimî Adalet Divanı, Wimbledon Buharlı Gemisi Davası'nda ${ }^{21}$ bu hususu, "Divan, bir Devletin, belli bir davranışta bulunma veya bir davranışta bulunmaktan kaçınma yükümlülüğ̈̈ altına girdiği herhangi bir andlaşmanın sonucunda egemenliğinden vazgeçtiği görüşünü kabul etmemektedir. Şüphe yoktur ki, bu türde bir yükümlülük meydana getiren herhangi bir andlaşma, Devletin egemenlik yetkilerinin icrasına, bu yetkilerin belli bir şekilde kullanılması anlamında, kısıtlama getirir. Ancak, uluslararası sözleşmelere (taahhütlere) girebilme hakkı, Devlet egemenliğinin bir sembolüdür."22 şeklinde ifade etmektedir.

Uluslararası hukukta uyuşmazlıkların çözümü de - ve özel olarak inceleme kapsamındaki deniz alanlarının sınırlandırılmasına ilişkin uyuşmazlıklar bakımından da - aynı prensipler geçerlidir. Hiçbir devlet rızası olmaksızın tarafı olduğu bir uyuşmazlığı uluslararası bir mahkeme önüne götürmek konusunda zorlanamayacaktır. ${ }^{23}$

Bu başlık altında, deniz alanlarının belirlenmesinde ortaya çıkan uyuşmazlıkların uluslararası yargı mercileri - özellikle de Uluslararası Adalet Divanı - önüne götürülmesi hususu, 1982 tarihli Birleşmiş Milletler Deniz Hukuku Sözleşmesi de göz önünde bulundurularak, tarafların rızalarının varlı̆̆ı ve yokluğu durumları bakımından ayrı ayrı ele alınmaya çalışılacaktır.

\section{A. BIRLEŞMIŞ MILLETLER DENIZ HUKUKU SÖZLEŞMESI'NDE ÖNGÖRÜLEN UYUŞMAZLIK ÇÖZÜM YÖNTEMLERI}

1982 BMDHS, uyuşmazlıkların çözümüne dair Kısım XV’de, sözleşmenin uygulanması veya yorumlanmasına ilişkin uyuşmazlık çözümünde Birleşmiş Milletler Şartı́nın 2/3 hükmüne de uygun olarak barışçıl yöntemlerin kullanılmasını öngörmektedir. Bu tür bir çözüm metodunu taraflar kendi aralarında belirleyebilirler. Eğer bahsi geçen barışçıl çözüm yollarıyla bir sonuca varılamamış ise, Kısım XV Bölüm 2 hükümlerine göre uyuşmazlığın taraflarından birisi, yetkisi olan bir mahkemeye veya tahkim merciine uyuşmazlığı götürebilecektir. ${ }^{24}$

Birleşmiş Milletler Şartı’nın 33. ve 95. maddelerinde de yer aldığı üzere, uluslararası hukukta, uyuşmazlık çözüm usullerinin seçiminde serbestlik ilkesi kabul edilmektedir. İlkenin deniz

20 Erkiner, Devletin Sorumluluğu (n 18) 4; Hakkı Hakan Erkiner, 'Devletin Haksız Fiilden Dolayı Uluslararası Sorumluluğunda Uluslararası Hukuk Komisyonu’nun Tespit Ettiği İsnat Kuralları’ (2007) 13(3-4) MÜHF-HAD 149.

21 S.S. "Wimbledon", Judgment (Series A No. 1, PCIJ Reports 1923).

22 Ibid 25; Karar metninin çevirisi için bkz. Mehmet Emin Büyük, "Uluslararası Adalet Divanı - "Wimbledon” Buharlı Gemisi Davası’ (2018) 25 Küresel Bakıș Çeviri Hukuk Dergisi 35-52; Kararın özet metni için ayrıca bkz. Mehmet Emin Büyük, Uluslararası Daimi Adalet Divanı - Kararlar, Danışma Görüşleri ve Emirnameler (1922-1930) (Beta 2020) 28-36.

23 Hakkı Hakan Erkiner, 'Birleşmiş Milletler Uluslararası Adalet Divanı Kararlarının Birleşmiş Milletler Güvenlik Konseyi Aracılığıyla Uygulatılması’ 2017 23(2) MÜHF-HAD 90.

24 Birleşmiş Milletler Deniz Hukuku Sözleşmesi, md. 279-281, Kuran ve diğerleri (n 15) 445. 
hukukuna yansıması ise 1982 BMDHS m. 287'de görülmektedir. ${ }^{25}$ Kısım XV Bölüm 2'de yer alan Madde 287/1'de; “Bu Sözleşme'yi imzalarken, onaylarken veya ona katıllrken yahut daha sonra herhangi bir zamanda bir devlet yazılı bildirim ile bu Sözleşme’nin yorumlanması veya uygulanması ile ilgili uyuşmazlikların çözümlenmesi konusunda aşağıdaki araçlardan birisini veya daha fazlasını seçmekte serbest olacaklardır: i. Ek VI’ya göre kurulmuş olan Uluslararası Deniz Hukuku Mahkemesi (International Tribunal for the Law of the Sea), ii. Uluslararasi Adalet Divani (International Court of Justice), iii. Ek VII'ye göre oluşturulan tahkim mahkemesi (Annex VII Arbitral Tribunal), iv. Ek VIII'de belirtilen uyuşmazlık kategorilerinden (balıkçılı, deniz çevresinin korunması ve muhafazası, bilimsel deniz araştırmaları, gemilerden kaynaklanan kirlenme de dâhil olmak üzere seyrüsefer konuları) biri veya daha fazlası için Ek VIII'e göre oluşturulan tahkim mahkemesi (Annex VIII Arbitral Tribunal)" denilmektedir. ${ }^{26}$

Sözleşme’nin hazırlık safhasında uyuşmazlık çözümüne ilişkin farklı fikirler ortaya çıkmış; bu görüşmeler sonucunda, öne sürülen dört farklı yargısal çözüm yolunu da içeren ve bu yargısal çözüm yolları içerisinden çözüm yapılabilmesini sağlayan bir sistem öngörülmüştür. Burada öncelikle 1982 Sözleşmesi'ne taraf olan devletlerin, aynı uyuşmazlık çözüm yöntemini seçmiş olup olmadıklarına bakılır. Eğer taraflar aynı uyuşmazlık yöntemini seçmişler ve bu hususta aksi bir anlaşmaya varmamışlarsa uyuşmazlık zorunlu olarak bu yargısal çözüm yoluna havale edilir. Eğer farklı çözüm yollarını kabul etmişlerse ve aksi yönde bir anlaşmaya varılmamış olursa uyuşmazlık zorunlu olarak Ek VII uyarınca teşkil edilecek tahkim mahkemesine havale edilir. Bu ihtimaller dışında, 1982 Sözleşmesỉne taraf ancak herhangi bir uyuşmazlık çözüm yöntemi seçimine dair bildirimde bulunmamış veya yaptığı bildirimin kapsamının dar olması nedeniyle tarafı olduğu uyuşmazlık bu usulün dışında kalmış bir devlet, Ek VII uyarınca teşkil edilecek tahkim mahkemesine gitmeye rıza göstermiş kabul edilir. ${ }^{27}$

Kısım XV Bölüm 1 ve 2'de yer alan bu düzenlemelerin yanında, Bölüm 3’te zorunlu yargı yetkisine dair istisnalara yer verilmiştir. Bu çalışmanın konusu bakımından da önemli olarak, 298. madde Bölüm 2'nin uygulanabilirliğine dair ihtiyari istisnaları konu edinmektedir ve hemen ilk paragrafta, sözleşmenin tarafı olan devletlerin, sınırların tespitiyle ilgili 15,74 ve 83 . maddelerin - yani kıyıları bitişik veya karşı karşıya olan devletler arasında karasuları, münhasır ekonomik bölge ve kıta sahanlığı sınırlandırmalarına ilişkin maddelerin - yorumlanması veya uygulanmasına dair uyuşmazlıklar bakımından, yazılı bir beyanla, BMDHS'de öngörülen uyuşmazlık çözüm yollarını kabul etmediklerini bildirebileceklerdir. Bu bildirim imzalama, onaylama veya katılma aşamasında olabileceği gibi, daha sonraki bir aşamada da yapılabilir. ${ }^{28}$

Sonuç olarak, BMDHS'ye taraf olan devletler bakımından deniz alanlarının sınırlandırılmasına ilişkin uyuşmazlıkların her durumda barışçıl çözüm yollarıyla çözülmesi esastır. Taraflar aralarında BM Şartı’nda da öngörülen bir uyuşmazlık çözümü yöntemi belirleyebilirler. Eğer bu yolla çözüm

25 Abdulkadir Gülçür, Uluslararası Deniz Hukuku Mahkemesinin Yapısı ve Yargı Yetkisi (On İki Levha Yayıncılık 2017 ) 29.

26 Birleşmiş Milletler Deniz Hukuku Sözleşmesi, md. 287/1, Kuran ve diğerleri (n 15) 447.

27 Gülçür (n 25) 29-30.

28 Birleşmiş Milletler Deniz Hukuku Sözleşmesi, md. 297-298, Kuran ve diğerleri (n 15) 451-453. 
mümkün olmazsa, BMDHS'de öngörülen çözüm yöntemlerinden birine taraflardan birinin tek taraflı başvurusuyla gidilebilir. Burada zorunlu yargı yetkisi öngörülmektedir. Gidilecek yargı veya tahkim organı tarafların önseçimine göre değişebilir. Eğer her iki taraf da bir çözüm yöntemi belirlememişse Ek VII uyarınca oluşturulacak tahkim mahkemesine gidilir. Ancak tüm bu olasilıklar, tarafların sınırlandırmaya ilişkin meseleleri Sözleşme kapsamındaki çözüm yöntemleri bakımından istisna olarak bildirmemiş olmaları şartına bağlıdır. Tabidir ki, bildirimde bulunan devletin bu bildirimi geri alabilmesi veya almamış olsa bile, böyle bir bildirimde bulunmamış bir devlete karşı bu istisna kapsamında yer alan bir uyuşmazlığı Sözleşme kapsamındaki uyuşmazlık çözümü merciilerine havale etmesi mümkündür.

\section{B. DENIZ ALANLARININ SINIRLANDIRILMASINA ILIŞKIN MESELELER BAKIMINDAN ULUSLARARASI ADALET DIVANI'NIN YARGI YETKISI}

Uluslararası Adalet Divanı'nın yargı yetkisi tarafların rızaları üzerinde temellenmektedir. Divan, sadece rızası olan devletler üzerinde yargı yetkisi icra edebilir ve aynı şekilde, yargılamaya taraf olmayan üçüncü devletlere ilişkin hukuki meselelere dair kararlar veremez. Bu ilkelerin bir sonucu olarak, Divan, aslında rızası bulunmayan üçüncü bir devlet aleyhine dava açmış olan devletlerin aralarındaki davaya bakmayacaktır. Doktrinde Monetary Gold ${ }^{29}$ ilkesi olarak adlandırılan bu kurala ilgili davada özel olarak vurgu yapılmış ve üçüncü bir devletin hukuki menfaatlerinin esaslı bir unsur teşkil ettiği davalarda, Divan’ın bu devletin yokluğunda davaya bakamayacağ ifade edilmiştir. ${ }^{30}$

Aşağıda açıklanacağı üzere, rızanın belirli bir şekilde olması gerekliliği bulunmamaktadır ve hatta bazı durumlarda Divan, tarafların davranışlarından bu tür bir rızanın varlığı sonucunu çıarmaktadır. Ancak her durumda rızanın kesin bir biçimde var olması gerekir. Rıza varsayılamaz. Duruma göre rızanın varlığı çıkarıma dayansa da Divan’n, Korfu Boğazı davasında ifade ettiği üzere, bu şekilde varsayılan bir rızanın "gönüllü ve tartışılmaz" olarak görünür olması gereklidir. ${ }^{31}$

Konu bakımından yetki bakımından, uzmanlaşmış mahkemelerden farklı olarak Divan, tarafların kendisine sunacağı herhangi bir meseleye bakmak konusunda yetki sahibidir. ${ }^{32}$ Dolayısıyla Uluslararası Adalet Divanı, deniz alanlarının sınırlandırılmasına ilişkin davalara da bakabilir. Divan tarafından görülen bu tür davalara örnek olarak 1951 tarihli İngiliz-Norveç Balıkçılık Davası, 1969 tarihli Kuzey Denizi Kıta Sahanlığı Davası, 1982 tarihli Tunus-Libya Kita Sahanlığı Davası, 1984 tarihli Maine Körfezi’nde deniz alanlarının belirlenmesi Davası ve 2009 tarihli Romanya ve Ukrayna arasında Karadeniz’de deniz alanlarının sınırlandırılması Davası örnek olarak verilebilir.

Devletlerin, Divanın yargı yetkisini tanımaları veya buna dair rıza göstermeleri ise farklı yollarla olabilir.

29 İlgili dava için bkz. Monetary Gold Removed from Rome in 1943 (Preliminary Question), Judgment (ICJ Reports 1954).

30 Malcolm Shaw, International Law (8th, Cambridge University Press 2017) 816-818.

31 Ibid 817-818.

32 Uluslararası Adalet Divanı Statüsü, md. 36/1, Kuran ve diğerleri (n 15) 36. 
- Taraflar aralarındaki uyuşmazlıkla ilgili bir tahkimname (special agreement; compromis) düzenleyebilir ve konuyu Divana havale edebilirler. Uyuşmazlıkların Divan önüne taşınması bakımından en sık uygulanan yöntem tahkimname düzenlenmesi yoludur. Bu sayede taşınan uyuşmazlığın ve Divan’n yargı yetkisinin de sınırları belirlenmiş olur. ${ }^{33}$ Bahse konu sınırlandırmaya ilişkin uyuşmazlıklar bakımından da bu hususa dair önemli bir örnek Kuzey Denizi Kıta Sahanlığı Davaları’nda Divan’n yetkilendirildiği tahkimnamede ortaya konulmuştur. Almanya-Hollanda ve Almanya-Danimarka arasındaki bu davalarda Divan'dan doğrudan sınırlandırmayı belirlememesi, bunun yerine Kuzey Denizi’nde yapılması planlanan kıta sahanlığı sınırlandırmasında uygulanacak uluslararası hukuk kurallarını ve ilkelerini belirlemesi istenmiştir. Taraflar, bu ilke ve kurallara göre sınırlandırmayı kendilerinin belirleyecekleri konusunda anlaşmışlardır. Yine aynı şekilde, usul hukukuna ilişkin olarak, yazışma ve duruşmaların sıralaması bakımından Almanya davacı olarak gösterilmiş ancak bu durumun ispat yükümlülüğü hususuna halel getirmeyeceği ifade edilmiştir. Tüm bunların yanında, ayrı iki tahkimname hazırlanmış olmasına rağmen Divan'dan davaları birleştirmesi istenmiştir ve Divan bu iki davayı tek bir dava olarak birlikte ele almıştır. ${ }^{34}$

- Devletlerin yaptıkları bazı andlaşmaların, andlaşmaya dair uyuşmazlıklarda Divanın yetkili olacağına dair bir hüküm içermesi durumunda da Divan’n yargı yetkisi tesis edilmiş kabul edilmektedir. Bu tür düzenlemeler yetki sözleşmesi veya yetki kaydı olarak bilinmektedir. Yukarıda açıklanan BMDHS, Divan’a seçimlik yetki vermesi bakımından buna dair bir örnek olarak verilebilir. Yine 1928 tarihli Uyuşmazlıkların Çözümüne Dair Genel Senet de bu niteliktedir. ${ }^{35}$

- Divan’n yargı yetkisinin tesis edilmesine dair diğer bir yöntem ise, tek taraflı bildiri yöntemidir. İhtiyari kayıt olarak adlandırılan bu yöntem, Divan Statüsü’nün 36/2 maddesinde düzenlenmiştir. İlgili paragraf şu şekildedir: " 2 - İş bu Statüye taraf olan devletler, herhangi bir zaman, aynı vecibeyi kabul eden herhangi bir devlete karşı, konusu aşă̆ıda gösterilmiş olan hukuki mahiyetteki uyuşmazlıkların hepsi hususunda Divan’n yargı yetkisini bihakkın (ipso facto) ve özel anlaşma (special agreement) olmaksızın, zorunlu olarak tanıdıklarını beyan edebilirler: a) bir andlaşmanın yorumlanması; b) Devletlerarası hukuka dair her husus; c) gerçekleşmesi halinde devletlerarası bir taahhüdün ihlalini teşkil edebilecek her olayın gerçekliği; d) uluslararası yükümlülüğün ihlalinin gerektirdiği tazminatın mahiyeti ve kapsamı."

Türkiye 12 Mayıs 1947 tarih ve 5047 sayılı kanunla Divan’n zorunlu yargı yetkisini 5 ylllık süre için ve belli çekincelerle kabul etmiştir. Bu beş yıllık sürenin dolmasından sonra, yine 4 ayrı dönem 5’er yıllık süreler ve aynı çekincelerle süre uzatılmıştır. Divan’ın zorunlu yargı yetkisinin tanınmasına dair en son beyanın süresi 23 Mayıs 1972 tarihinde dolmuş ve bu tarihten sonra, Türkiye zorunlu yargı yetkisinin tanınmasına dair herhangi bir beyanda bulunmamış ve bu durum günümüze kadar da devam etmiştir. ${ }^{36}$

33 Yusuf Aksar, Teoride ve Uygulamada Uluslararası Hukuk II (3. Baskı, Seçkin 2015) 268-269; Melda Sur, Uluslararası Hukukun Esasları (8. Bask1, Beta 2014) 196.

34 Günther Jaenicke, 'North Sea Continental Shelf Cases' in Rudolf Bernhardt (ed) 2 Encyclopedia of Public International Law (North Holland, Elsevier 1981) 206.

35 Aksar (n 33) 269-270; Sur (n 33) 196.

36 Aksar (n 33) 270-273; Sur (n 33) 196. 
- Son olarak Divan'ın yargı yetkisinin tanınması, forum prorogatum olarak adlandırılan, bir anlamda davanın taraflarından biri bakımından yargı yetkisinin dolaylı olarak tesis edilmesidir. Divan önüne, Divan’n zorunlu yargı yetkisini daha önce tanımamış olan bir devlet aleyhine bir dava getirildiğinde, bu devletin davranışlarından Divan’ın yargı yetkisinin doğması mümkündür. Yukarıda ifade edildiği üzere, rızanın her durumda açık bir şekilde anlaşılması gerekir. Korfu Boğazı davasında olduğu gibi, verilen cevapta yargı yetkisinin kabul edildiği bildirilebileceği gibi, Divan önünde davaya ilişkin prosedürlere katılma veya Divan’n yetkisizliğinin ileri sürülmemesi gibi durumlarda forum prorogatum yoluyla Divan’n yetkilendirilmesi mümkündür. ${ }^{37}$

Çalışmanın konusu açısından da önemli olarak, Ege Denizi’ndeki kıta sahanlığı sınırlandırmasına dair uyuşmazlık, taraflar arasındaki görüşmelerin sonuçsuz kalması üzerine, tek taraflı olarak Yunanistan tarafından, 7 Ağustos 1976 tarihli bir dilekçeyle Divan’a sunulmuştur. Türkiye, Divan’a, davaya bakma konusunda yetkisinin olmadığını belirttiği bir dilekçeyi, diğer iddialarıyla birlikte 25 Ağustos 1976 tarihinde yollamıştır. Aynı şekilde yargılamanın hiçbir aşamasında da yer almamıştır. Türkiye, Yunanistan Divan’ın yargı yetkisine ilişkin öne sürdüğü 1928 tarihli Uyuşmazlıkların Barış̧̧l Çözümüne Dair Genel Senet'in yürürlükte olmadığını, olsaydı bile Yunanistan’n ülke statüsüne ilişkin konular bakımından çekince koyduğunu ileri sürmüştür. Divan, bahsi geçen sözleşmenin geçerliliği konusunu ayrıca ele almamış ancak çekincenin yargı yetkisinin tesisine engel olduğu sonucuna ulaşmıştır. Sonuç olarak Divan, 19 Aralık 1978 tarihli kararında, Yunanistan’n tek taraflı başvurusuyla önüne getirilen Ege Denizi Kita Sahanlığı Davası’nda 2 olumsuz oya karşı 12 oyla yargı yetkisinin bulunmadığına hükmetmiştir. ${ }^{38}$

Sonuç olarak, deniz alanlarının sınırlandırılması bakımından, BMDHS'ne taraf olmayan bir devlet bakımından ortaya çıkan uyuşmazlıklar açısından Divan’n yargı yetkisi, ancak tarafların bu hususta rızalarının varlığı halinde söz konusu olacaktır. Hiçbir devlet, bu türden bir uyuşmazlığını, yukarıda belirtilen yargı yetkisinin kabulüne ilişkin yöntemlerden biri mevcut değilse, Divan’a götürmek veya karşı taraf böyle bir başvuruda bulunmuşsa davaya taraf olmak zorunda değildir. ${ }^{39}$

\section{KITA SAHANLIĞI SINIRLANDIRMASINA ILIŞKIN YARGI KARARLARI VE EGE DENIZI BAKIMINDAN OLASI SONUÇLAR}

\section{A. KITA SAHANLIĞI SINIRLANDIRMASINDA IÇTIHAT HUKUKUNUN GELIŞiMi40}

1982 Birleşmiş Milletler Deniz Hukuku Sözleşmesi'nde kıyıları karşı karşıya veya bitişik olan devletler arasında kıta sahanlığı (münhasır ekonomik bölge sınırlandırması bakımından da aynı

37 Aksar (n 33) 273-275; Sur (n 33) 196-197.

38 Oellers-Frahm (n 7) 5-7; Aksar (n 33) 275.

39 Hakkı Hakan Erkiner, Birleşmiş Milletler Uluslararası Adalet Divanı Kararlarının Birleşmiş Milletler Güvenlik Konseyi Aracılığıyla Uygulatılması' 2017 23(2) MÜHF-HAD 89.

40 Bkz. Kuran (n 4) 233-239; Toluner (n 2) 202-247; Pazarcı (n 5) 371-374; Yücel Acer, 'Ege Kita Sahanlığı Sorunu ve Uluslararası Yargı Kararları’ iç Aslan Gündüz ve Hüseyin Öztürk (edr) Ege Kıta Sahanlı̆̆ı ve İlişkili Sorunlar Sempozyumu Bildiriler Kitabı (Türk Deniz Araştırmaları Vakfı 2002) 60-80; Yoshifumi Tanaka, The International Law of the Sea (Cambridge University Press 2012) 192-198; Yoshifumi Tanaka, Predictability and Flexibility in the Law of Maritime 
kurallar geçerlidir) sınırlandırmasına ilişkin getirilen düzenleme, Divan uygulamaları ışı̆̆ında ortaya çıkmıştır. Bu bakımdan, söz konusu maddenin yorumlanması ve uygulanmasında Divan’nn ve ilgili diğer mahkemelerin kararları ışı̆ı̆nda yorumlanması gerekmektedir. Diğer bir ifadeyle, deniz alanlarının sınırlandırılması, büyük oranda içtihatlarla şekillendirilmiş bir alandır. Aşağıda ayrıntıları ile ifade edileceği üzere bu kararlarda ortaya çıkan genel eğilim, hakça ilkeler başlığı altında hakkaniyete önem veren, eşit uzaklık ve orta hat ilkelerinin, hakkaniyete uygun bir sonuç verdiği durumlarda uygulandığı, adaların statüsünün anakaralardan farklı olarak ayrıca değerlendirildiği bir görünüm arz etmektedir. ${ }^{41}$

Kıta sahanlığ sınırlandırmasına ilişkin içtihat hukukunu 1969 Kuzey Denizi Kıta Sahanlı̆̆ 1 Davaları ${ }^{42}$ ile başlatmak mümkündür. Yukarıda da ifade edildiği üzere, 1958 Sözleşmesi, kıyıları karşılıklı veya bitişik olan devletler açısından kıta sahanlığ sınırlandırmasının öncelikle anlaşma yoluyla olmasını; anlaşmanın olmadığı ve özel şartların haklı kılmadığı durumlarda ise ortay hat metoduyla sinırlandırmanın belirlenmesini öngörmektedir. Tarafların talebine uygun olarak sonradan tek bir dava olarak birleştirilen Almanya-Hollanda ve Almanya-Danimarka arasındaki bu uyuşmazlıklar, Kuzey Denizi’nde yapılacak kıta sahanlığı sınırlandırmasında uygulanacak ilkelerin ne olduğunun Divan tarafından belirlenmesi talebiyle yargı organı önüne getirilmiştir. Federal Almanya Cumhuriyeti, 1958 Cenevre Kıta Sahanlığı Sözleşmesỉne taraf değildi. Bu bakımdan eşit uzaklık ilkesinin kendisi açısından bağlayıcı olmadığını ileri sürmekteydi. Danimarka ve Hollanda ise, tüm sınır çizgilerinin eşit uzaklık ilkesine göre belirlenmesi gerektiğini iddia etmekteydi; davanın bu taraflarına göre eşit uzaklık ilkesi ve bu ilkenin düzenlendiği 1958 Sözleşmesi’nin 6. maddesi teamül kuralı niteliği kazanmıştı. Almanya, içbükey (konkav) sahil şeridinden dolayı, bu metodun hakkaniyetli olmadığını düşünmekteydi zira eşit uzaklık yöntemiyle Almanyảnın kıta sahanlığı alanı daralmaktayd. ${ }^{43}$

Divan, eşit uzaklık ilkesinin, Danimarka ve Hollanda’nın iddialarının aksine, henüz bir teamül kuralı niteliği kazanmadığına, dolayısıyla Almanya bakımından bağlayıcı olmadığına karar vermiştir. ${ }^{44}$ Divan’a göre her durumda uygulanabilecek sabit bir sinırlandırma metodu bulunmamaktadır. Sınırlandırma yapılırken öncelikli amaç hakça çözüme ulaşılmasıdır. ${ }^{45}$ Divan’n bu davada kıta sahanlığının kara ülkesinin deniz tabanına doğru uzaması anlamında doğal uzantısı olması hususuna ayrıca vurgu yaptığı da belirtilmelidir.

Delimitation (Hart Publishing 2006); Lucius Caflisch, 'Maritime Boundaries, Delimitation' in Rudolf Bernhardt (ed.), 11 Encyclopedia of Public International Law (North Holland, Elsevier 1989) 212-219; Malcolm N. Shaw, Uluslararast Hukuk, (çev.) İbrahim Kaya ve diğerleri, (8th Ed., Türkiye Bilimler Akademisi 2018) 420-430; Louis B. Sohn, Cases and Materials on the Law of the Sea (2nd, Brill Nijhoff 2014) 269-342; United Nations Handbook on the Delimitation of Maritime Boundaries (United Nations Publications 2002); James Crawford, Brownlie's Principles of Public International Law (8th, Oxford University Press 2012) 281-293; Malcolm D. Evans, The Law of the Sea' in Malcolm D. Evans (ed), International Law (Oxford University Press 2003) 647-650.

41 Toluner (n 2) 227-228.

42 North Sea Continental Shelf Cases, Judgment (ICJ Reports 1969).

43 Jaenicke (n 34) 205-206.

44 North Sea Continental Shelf (n 42) 38.

45 North Sea Continental Shelf (n 42) 53; Ayrıca bkz. Mehmet Emin Büyük, Uluslararası Hukukta Hukukun Genel İlkeleri (On İki Levha Yayıncılık 2018) 286 vd. 
1977-78 yıllarında Tahkim Mahkemesi'nce verilen İngiltere-Fransa Kıta Sahanlığı Davası’na ${ }^{46}$ ilişkin kararlarda ise, Kuzey Denizi Kıta Sahanlığ ${ }_{1}$ Davası'ndan farklı bir düşünce üzerinden benzer bir sonuca ulaşılmıştır. Bu davanın tarafı olan devletler, aynı zamanda 1958 Kıta Sahanlığı Sözleşmesỉne de taraftırlar. Divan tarafından verilen karardan farklı olarak, Tahkim Mahkemesi, 1958 Sözleşmesi'nde ifade bulan "eşit uzaklık - özel durumlar" kuralının birlikte uygulanmasını, hakça ilkeler teamül hukuku kuralıyla eşitlemiştir. ${ }^{47}$ Buna göre, 1958 Sözleşmesi’ndeki “6. maddenin, birleşik eşit uzaklık-özel koşullar kuralı olan genel geçer bir kural içerdiği ve bu kuralın uygulamada anlaşmaya varılamamasının devletler arasındaki aynı kıta sahanlığına bitişik sınırın hakça ilkelere uygun biçimde belirlenmesi gerektiğine ilişkin genel norma belirli bir anlam kattığı sonucuna varılmıştır.”48

Böylece Tahkim Mahkemesi, mevcut vakada herhangi bir özel durumun varlığı söz konusu olsa dahi eşit uzaklık metodunu bir başlangıç noktası olarak ele almıştır. Bu yöntemle Mahkeme, hakça ilkeler bir düzeltici unsur olarak değerlendirmiştir. Dolayısıyla iki aşamalı bir sınırlandırma metodunun ortaya çıktığı söylenebilir: ilk aşamada eşit uzaklık yöntemiyle bir ortay hat çizilecek, daha sonra ise özel durumlara göre bu hat üzerinde gerekli değişiklikler yapılarak sınırlandırma hakça bir çözüme kavuşturulacaktır. ${ }^{49}$ Sonuç olarak, yeniden ifade edilecek olursa, Tahkim Mahkemesi’ne göre 1958 Sözleşmesi'nde de teamül hukukuna uygun olarak, kıta sahanlığı sınırlandırmasının hakça ilkelere göre yapılması öngörülmektedir.

1982 yılında Uluslararası Adalet Divanı tarafından verilen Tunus-Libya Kıta Sahanlığı Davası'na ${ }^{50}$ ilişkin kararda da Divan’ın hakça ilkelere göre sınırlandırma içtihadını sürdürdüğü görülmektedir. $\mathrm{Bu}$ davanın tarafları olan devletler 1958 Sözleşmesi’ne taraf değillerdir. Uyuşmazlığın Divan’a sunulmasına ilişkin tahkimnamede, Divan'dan, Üçüncü Deniz Hukuku Konferans’ındaki eğilimlere ve "hakça ilkeler" ve bölgeyle "ilgili durumlar"a göre karar vermesi istenmiştir. Divan’ın sınırlandırma bakımından hakkaniyetin yerine getirilmesine özel bir vurgu yaptığı görülmektedir. Diğer yandan, doğal uzantı kriterinin belli bir önemi bulunsa da, hakkaniyetin gerçekleştirilmesinin yanında görece arka plana düştüğü ifade edilmiştir. Kaldı ki, sınırlandırmayla ilgili bölgenin tek bir kıta sahanlığı teşkil etmekte olup, doğal uzantı ilkesinden yola çıkılarak belirlenecek bir sınırlandırma kriteri dava bakımından hakkaniyetli çözüme ulaştırmayacaktır. ${ }^{51}$

12 Ekim 1984 tarihinde Uluslararası Adalet Divanı Basit Yargılama Dairesi tarafından karara bağlanan Amerika Birleşik Devletleri ve Kanada arasındaki Maine Körfezi bölgesindeki kıta sahanlığı ve balıkçılık bölgelerinin tek bir sınır olarak belirlenmesi için açılan davada ${ }^{52}$ yargı merci,

Delimitation of the Continental Shelf between the United Kingdom of Great Britain and Northern Ireland, and the French Republic (UK, France), 30 June 1977 - 14 March 1978, XVIII Reports of International Arbitral Awards (United Nations 2006) 3-413.

47 Tanaka, Law of the Sea (n 40) 242.

48 Shaw, Uluslararası Hukuk (n 40) 422.

49 Tanaka, Law of the Sea (n 40) 242.

50 Case Concerning the Continental Shelf (Tunusia/Libyan Arab Jamahiriya), Judgment (ICJ Reports 1982).

51 Kuran (n 4) 236; Tanaka, Law of the Sea (n 40) 243.

52 Case Concerning Delimitation of the Maritime Boundary in the Gulf of Maine Area (Canada/United States of America), Judgment, ICJ Reports, 1984. 
tüm sınırlandırma uyuşmazlıklarına uygulanacak birtakım kurallar belirlemiştir. Bunlardan ilki, sınırlandırmanın öncelikle taraflar arasında iyi niyet çerçevesinde yapılacak anlaşmayla yapılmasıdır. Dolayısıyla sınırlandırma, kıyıları karşılıklı veya bitişik olan devletler bakımından, tek taraflı olarak yapılamaz. İkinci olarak da, "her durumda, hakça kriterlerin uygulanması ile ve bölgenin coğrafi şekli ve diğer ilgili durumlara ilişkin olarak hakça bir sonuç ortaya çıkmasını mümkün kılacak pratik yöntemlerin kullanımı yoluyla ortaya konulmalıdır." 53 Divan Dairesi'nin hakça ilkelere göre yapılması istenen sınırlandırma açısından davadan davaya değişebilecek "hakça kriterler" ve "pratik yöntemler" gibi kavramlara gönderme yaptı̆̆ görülmektedir. ${ }^{54}$

Uluslararası Adalet Divanı tarafından kıyıları karşılıklı olan Libya ve Malta devletleri arasındaki kıta sahanlığı sınırlandırması uyuşmazlığında ${ }^{55}$ da 1958 Sözleşmesi’ne Libya’nın taraf olmaması nedeniyle davayı teamül hukukuna göre çözüme kavuşturduğu görülmektedir. Divan’a göre doğal uzantı gibi coğrafi kriterler tek belirleyici unsur olmadığı gibi, eşit uzaklık da sınırlandırmada kullanılacak tek yöntem değildir. Dolayısıyla hakça ilkelerin de dikkate alınması gereklidir. "Kararda, bu hakça ilkelerin neler olabileceğine dair birtakım örnekler sayılmıştır. Buna göre, bir tarafın diğerine ait alanları ihlal etmemesi, ilgili tüm durumların göz önünde bulundurulması, eşitliğin mutlak anlamda hakkaniyetli sonuca ulaştıramayabileceği gibi ilkeler ilgili durumlar ışı̆̆ında göz önünde bulundurulmalıdır. Divan, bu hususlar doğrultusunda, kıyı şeritlerinin özellikleri, aralarındaki uzaklık ve uzunluklarını dikkate almış ve tarafların kıyı şeritlerinin uzunluğuyla kıta sahanlıkları arasında bir orantısızlı̆̆ı ortaya çıkmasından özellikle kaçınmıştır."56

Tahkim Mahkemeleri tarafından verilen 1985 tarihli Gine/Gine-Bissau Tahkimi'nde ${ }^{57}$ ve 1992 tarihli St. Pierre ve Miquelon Tahkimi'nde ${ }^{58}$ de bu döneme kadar olan hakça ilkeler temelli yaklaşımın aynı şekilde kabul edildiği görülmektedir. Özellikle de, aşağıda da değinileceği üzere, 1985 tarihli tahkim kararında, kıyı önünde bulunan çok sayıda adanın varlığı sebebiyle eşit uzaklık ilkesinin öncelikli uygulama alanı bulamayacağı ifade edilmiştir. İlgili mahkemeye göre sınırlandırma işleminin amacı, vakaya ilişkin koşullar bağlamında hakça çözüme ulaşılmasıdır. Davanın çözümlenmesinde de doğal uzantı ve ekonomik faktörlere sıklıkla atıf yapılmıştır. ${ }^{59}$

1993 tarihli Jan Mayen/Grönland Davası'yla birlikte Divan, sınırlandırmada uygulanan yöntem bakımından değişikliğe gitmiştir. Bu döneme kadar uygulanan yöntem hakça sonuçların ortaya çıkarılmasına yönelik daha esnek ve her bir vaka açısından yeniden oluşturulan sınırlandırma işlemlerini içerirken, bu dönemle birlikte hakça ilkeler ve eşit uzaklık prensibinin birlikte uygulandığ 1 ve hakkaniyetin uygulanan yöntem üzerinde düzeltici işlem olarak etki gösterdiği bir yöntemin

53 Gulf of Maine Case, s. 300.

54 Tanaka, Law of the Sea (n 40) 244; Kuran (n 4) 237.

55 Case Concerning the Continental Shelf (Libyan Arab Jamahiriya/Malta), Judgment (ICJ Reports 1984).

56 Kuran (n 4) 237.

57 Affaire de la délimitation de la frontière maritime entre la Guinée et la Guinée-Bissau, 14 Février 1985, XIX Recueil Des Sentences Arbitrales (Nations Unies 2006) 149-196.

58 Delimitation of Maritime Areas Between Canada and France, 10 June 1992, XXI Reports of International Arbitral Awards (United Nations 2006) 265-341.

59 Shaw, Uluslararası Hukuk (n 40) 424; ayrıca bkz. 425. 
uygulandığı görülmektedir. Aşağıda ifade edileceği üzere, üçüncü bir aşama olarak, 2009 yılındaki Karadeniz’de Deniz Alanlarının Sınırlandırılması Davası’yla birlikte üç aşamalı bir sınırlandırma işlemine geçildiği görülecektir. ${ }^{60}$

Danimarka ve Norveç arasındaki Jan Mayen Davası'nda ${ }^{61}$ balıkçılık alanları ve kıta sahanlığ sınırlandırmasına ilişkin talepler söz konusudur. Her iki devlet de 1958 Kıta Sahanlığ 1 Sözleşmesi’nin taraflarıdır. Tek bir deniz alanı sınırlandırması talebi söz konusu olmadığından her bir deniz alanı ayrı ayrı incelenmiştir. Öncelikle kıta sahanlığı bakımından, 1977 tarihli İngiltere-Fransa Kıta Sahanlığı Davası'na da atıfla, 1958 Sözleşmesi ve teamül hukukuna uygun olarak önce geçici bir ortay hattın çizilmesi, sonra da bu hattın değiştirilmesini gerektirecek “özel durumlar”ın var olup olmadığının inceleneceği ifade edilmiştir. Balıkçılık alanlarına uygulanacak hukuk bakımından, tarafların da rızasıyla münhasır ekonomik bölgeye ilişkin kurallar göz önünde bulundurulmuştur. Daha sonra da, kıta sahanlığı sınırlandırmasına ilişkin kurallarla balıkçılık alanlarına ilişkin kurallar teamül hukuku seviyesinde bir araya getirilmiştir. Bu bağlamda hem kıta sahanlığı için hem de balıkçılık alanları için öncelikle bir ortay hat çizilmesi ile sınırlandırma işlemi başlatılacaktır. Böylece içtihadın yönü düzeltici hakkaniyet yaklaşımına doğru değişmiştir. Bu yaklaşım bakımından eşit uzaklık ilkesinin hakça ilkeler kapsamında teamül hukuku içerisine alındığ ifade edilmelidir. $^{62} \mathrm{Bu}$ kararda Divan Dairesi'nin kıyı uzunlukları arasında karşılaştırma yaptığını ve Grönland'ın Jan Mayen'den dokuz kattan daha fazla kıyı uzunluğuna sahip olduğunu tespit ettiğini, aradaki bu farkın sınırlandırmada hesap edildiğini belirtmek gerekir. ${ }^{63}$

Jan Mayen Davası sonrası bir dizi kararda Divan’n ve birtakım tahkim mahkemelerinin bu yeni yöntemi uygulama konusu ettiği görülmektedir. 1999 tarihindeki Eritre/Yemen Tahkimi’nde ${ }^{64}$ Daimî Tahkim Mahkemesi’nin, 2001 tarihli Katar/Bahreyn ${ }^{65}$ ve 2002 tarihli Nijerya/Kamerun $^{66}$ davalarında da Uluslararası Adalet Divanı'nın düzeltici hakkaniyet yöntemiyle sınırlandırmayı belirledikleri görülmektedir. Eritre ve Yemen arasındaki davada, Tahkim Mahkemesi'nin adaları ileri sürerek daha fazla deniz alanı talep eden Yemen'in taleplerini kabul etmediğini; eşit uzaklık çizgisinin belirlenmesinde ise kıyılara yakın bazı adalara ağırlık verirken, birtakım adaları ise dikkate almadığını ayrıca belirtmek gerekir. ${ }^{67} 1982$ Sözleşmesi’nde münhasır ekonomik bölge ve kıta sahanlığı sınırlandırmalarını düzenleyen 74 ve 83 . maddelerde sınırlandırmaya ilişkin yöntemin somut olarak düzenlenmediği düşünüldüğünde, Divan’n yargı faaliyetinin yaratıcı yorumlama

60 Tanaka, bahsi geçen sınırlandırmaya ilişkin dönemsel üç yaklaşıma dair geniş bilgiler vermektedir. Ayrıntılı bilgi için bkz. Tanaka, Law of the Sea (n 40) 242-250.

61 Maritime Delimitation in the Area between Greenland and Jan Mayen (Denmark v. Norway), Judgment (ICJ Reports 1993).

62 Tanaka, Law of the Sea (n 40) 244-245.

63 Shaw, Uluslararası Hukuk (n 40) 426.

64 Eritrea/Yemen - Sovereignty and Maritime Delimitation in the Red Sea (Second Phase), Permanent Court of Arbitration, (17 December 1999), XXII Reports of International Arbitral Awards (United Nations 2006) 335-410.

65 Maritime Delimitation and Territorial Questions between Qatar and Bahrain (Qatar v. Bahrain), Judgment, (ICJ Reports 2001).

66 Land and Maritime Boundary between Cameroon and Nigeria, Judgment (ICJ Reports 2002).

67 Gökdemir-Işık (n 13) 120-121. 
faaliyeti teşkil ettiği ifade edilebilir. ${ }^{68} 2006$ tarihli Barbados/Trinidad ve Tobago arasındaki tahkim davasında ${ }^{69}$ ve yine 2007 tarihli Guyana/Surinam Tahkimi'nde ${ }^{70}$ de tahkim organlarının Divan'n belirlediği sinırlandırma metodunu uygulama konusu ettikleri görülmektedir. Öte yandan Uluslararası Adalet Divanı tarafından karara bağlanan 2007 tarihli Nikaragua/Honduras arasında deniz alanlarının sınırlandırılmasına ilişkin davada ${ }^{71}$ ise Divan’ın, sınırlandırmanın ilk aşamasında eşit uzaklık yoluyla orta hat çizilmesinin zorunlu olmadığını ifade ettiği görülmektedir. Divan, bu davada açırtay yöntemiyle tek bir sınır çizgisi belirlemiştir. Ancak yine de, eşit uzaklık metodunun genel kural olarak geçerliliğini koruduğunu özellikle ifade etmiştir. Hatta uyuşmazlık konusu deniz alanındaki adaların çevresindeki sınırlandırmalarda düzeltici hakkaniyet metoduyla sonuca ulaşmıştır. Bu bakımdan önceki içtihadından ayrılmasının kısmi olduğu söylenebilir. ${ }^{72}$

16 Eylül 2004 tarihinde Romanya’nın, "Karadeniz'de iki devlet arasında tek bir deniz alanı sınırlandırmasının tesis edilmesi ve böylelikle taraflara ait kıta sahanlığı ve münhasır ekonomik bölge alanlarının sınırlandırılması" talebiyle Ukrayna aleyhine açtığı dava üzerine Uluslararası Adalet Divanı, 2009 tarihli Karadeniz'de Deniz Alanlarının Sınırlandırılması Davası ${ }^{73}$ kararını açıklamıştır. Divan, bu davada kendisine getirilen deniz alanlarının sınırlandırılmasına ilişkin uyuşmazlıklarda belli aşamalar üzerinden ilerlediğini ifade etmiştir. Buna göre ilk önce geçici eşit uzaklık çizgisi çizilecektir. Sonraki ikinci aşamada hakça bir sonucun elde edilebilmesi için geçici eşit uzaklık çizgisinin düzenlenmesi veya değiştirilmesini gerektiren etkenlerin var olup olmadığını değerlendirecektir. İlgili dava bakımından bunlar (1) kıyı uzunlukları arasındaki olası orantısızlık; (2) Karadeniz'in kapalı yapısı ve bölgede halihazırda yapılmış olan sınırlandırmalar; (3) sınırlandırmaya konu bölgedeki Yılan Adası’nın varlığı; (4) tarafların faaliyetleri (petrol ve doğalgaz imtiyazları, balıkçılık faaliyetleri ve deniz devriyeleri); (5) taraflardan herhangi birinin kıta sahanlığı veya münhasır ekonomik bölge üzerindeki haklarına dair olası bir kısıtlama; ve (6) tarafların belirli güvenlik kaygıları.

Son olarak ve üçüncü aşamada ise Divan, çizginin (ilgili durumlar göz önünde bulundurularak ayarlanmış veya ayarlanmamış olabilecek bir geçici eşit uzaklık çizgisi), her bir devletin kıyı uzunlukları oranı ile bu sınırlandırma çizgisinin mevcut haliyle her bir devletin sahip olduğu ilgili deniz alanları oranı arasında belirgin bir orantısızlık nedeniyle hakça olmayan bir sonucu ortaya çıkarıp çıkarmadığı konusunu inceleyecektir. Hakça bir sonuç için son bir kontrol, kıyı uzunluklarının oranına kıyasla deniz alanları arasında büyük bir orantısızlığın belirgin olmadığına dair bir teyit gerektirmektedir. $^{74}$

Tanaka, Law of the Sea (n 40) 245-246.

Arbitration between Barbados and the Republic of Trinidad and Tobago, relating to the delimitation of the exclusive economic zone and the continental shelf between them, decision of 11 April 2006, XXVII Reports of International Arbitral Awards (United Nations 2008) 147-251.

Award in the arbitration regarding the delimitation of the maritime boundary between Guyana and Suriname, 17 September 2007, XXX Reports of International Arbitral Awards (United Nations 2012) 1-144.

Territorial and Maritime Dispute between Nicaragua and Honduras in the Caribbean Sea, Judgment (ICJ Reports 2007).

Tanaka, Law of the Sea (n 40) 246.

Maritime Delimitation in the Black Sea (Romania v. Ukraine), Judgment (ICJ Reports 2009).

Maritime Delimitation in the Black Sea, para. 115-122. 
Böylece Divan’ın içtihadında yeni bir aşamaya geçtiği söylenebilir. Divan, açık bir şekilde üç aşamalı bir sınırlandırma yöntemini formüle etmiştir. Önceki içtihatlarından farklı olarak, burada orantısızlık testi özel olarak ayrı bir aşama olarak ele alınmıştır.

Karadeniz'de Deniz Alanlarının Sınırlandırılması Davası’nın bu çalışma bakımından ayrı bir önemi de, dava bakımından önemli olan Yılan Adası'na kıta sahanlığı ve münhasır ekonomik bölge hakkının tanınıp tanınmadığg konusudur. Bu hususta Divan’ın değerlendirmeleri şu şekildedir:

"Yılan Adası'nın durumunun, eşit uzaklık çizgisinin tespit edilmesinde hususi bir incelemeye konu edilmesi gerekmektedir. Esas hat noktalarının seçimiyle bağlantılı olarak Divan, kıyı adalarının, özellikle de kıyının bir adalar saçağı kümesinden oluştuğu durumlarda, bir devletin kıyısının bir parçası olarak kabul edildiği durumlar olduğunu gözlemlemektedir. Nitekim bir deniz alanlarının sinırlandırlması tahkiminde, uluslararası bir mahkeme, esas hat noktalarını taraflardan birinin kıyı şeridinin bir parçası olarak düşünülen birtakım saçak adaların en düşük cezir çizgileri üzerine yerleştirmiştir (Award of the Arbitral Tribunal in the Second Stage of the Proceedings between Eritrea and Yemen (Maritime Delimitation), 17 December 1999, RIAA, Vol. XXII, pp. 367-368, paras. 139-146). Bununla birlikte, Yilan Adası, izole bir şekilde ve anakaradan 20 deniz mili kadar uzakta, Ukrayna'nın "kıyısı" $n ı$ oluşturan saçak adalar kümesinden bir ada olarak kabul edilemez.

Yılan Adası'nı kıyının bağlantılı bir parçası olarak kabul etmek, Ukrayna'nın kıyı şeridine yabancı bir unsurun eklemlenmesi anlamına gelecektir; bunun anlamı coğrafyanın hukuk yoluyla yeniden şekillendirilmesidir, ki ne hukuk ne de deniz alanlarının sınırlandırılmasına ilişkin uygulama böyle bir yetkiyi tanımaktadır. Dolayısıla Divan, Yılan Adasinın Ukrayna kıyı düzeninin bir parçasını oluşturamayacağı kanaatindedir (karşılaştırmak için bkz. Filfla kayalı̆̆ıın durumu: Continental Shelf (Libyan Arab Jamahiriya/Malta), Judgment, I.C.J. Reports 1985, p. 13).

Bu nedenle Divan, Romanya ve Ukrayna kıyıları arasında geçici eşit uzaklık çizgisinin tespit edilmesinde Yilan Adasindaki herhangi bir esas hat noktasını seçmenin uygun olmadiğını görüşündedir." 75

Divan’ın üç aşamalı sınırlandırma metodu yaklaşımının daha sonraki Uluslararası Adalet Divanı, Uluslararası Deniz Hukuku Mahkemesi ve Ek VII Tahkim Mahkemeleri tarafından da kabul edildiği görülmektedir. ${ }^{76}$

75 Maritime Delimitation in the Black Sea, para. 149. Adalar saçağı ve böyle bir coğrafyada esas hattın belirlenmesinde temel alınacak ilkeler ve Ege Denizi deniz alanları sınırlandırması bakımından değerlendirmesi için ayrıca bkz. Deniz Tekin Apaydın, Tekin-Apaydın D, 'Düz Esas Hatların Belirlenmesinde Adaların Rolü: Adalar Saçağı Bilmecesi' (2019) 25(2) MÜHF-HAD 565-589. Referans verilen çalışmada yazar Kuzey Denizi gibi birtakım örneklerde var olanın aksine Ege Denizi’nde adaları da içine alan bir düz esas hat sınırlandırmasının uluslararası hukuk ilkelerine uygun olmayacağına kanaatine ulaşmıştır - ki bu çalışmanın yazarları da aynı görüşü paylaşmaktadır. 
Verilen kararların bütününe ilişkin bir değerlendirme yapılacak olursa, Kuzey Denizi Kıta Sahanlığı ile başlayan süreçte 1958 Sözleşmesỉnin görünürdeki eşit uzaklığı önceleyen katı sınırlandırma sistemi başlangıçtan itibaren kabul görmemiştir. Öte yandan 1977-78 tarihli İngiltere-Fransa Kita Sahanlı̆̆1 Tahkimi'yle birlikte, 1958 Sözleşmesi de hakkaniyeti - veya hakça ilkeleri - içeren bir yorumla uygulanmaya başlanmıştır denilebilir. Jan Mayen Davası̀na kadar hakça çözüm amaçlı sonuç odaklı bir yaklaşım benimsenmiştir. Bu sayede ilgili yargı organları için daha esnek bir karar verme süreci ortaya çıkmışırı ancak davayı bu yargı organları önüne taşıyan taraflar açısından ise kısmi bir öngörülemezlik durumu söz konusudur. Uluslararası Adalet Divanı, Jan Mayen kararıyla birlikte sınırlandırma sürecinde izlenecek aşamaları ortaya koymuş; hakkaniyet ise eşit uzaklığın ortaya çıkaracağı adaletsiz durumlar açısından bir düzeltici işleve kavuşmuştur. Böylece verilecek karar açısından öngörülebilirlik de artmıştır. Son olarak Karadeniz'de Deniz Alanlarının Sınırlandırılması Davası ile birlikte sınırlandırma faaliyeti üç aşamalı bir işlem olarak uygulanmış ve ilk aşamada geçici bir eşit uzaklık çizgisi çizilmiş; ikinci aşamada hakça ilkelere göre - somut bir takım durumlar dahilinde - bu çizgide değişiklik yapılması veya yapılmaması hususu incelenmiş; son olarak da ortaya çıkan sınırlandırma orantısızlık testine tabi tutulmuştur.

\section{B. IÇTiHAT IŞIĞINDA ULUSLARARASI ADALET DIVANI'NINEGE DENIZI UYUŞMAZLIĞINA ILIŞKIN KARARINA DAIR ÖNGÖRÜLER}

1969 tarihli Kuzey Denizi Kita Sahanlı̆̆ Davası ve 1977-78 tarihli İngiltere/Fransa Kita Sahanlığı Tahkimi ile başlayan kıta sahanlığı sınırlandırmasına dair içtihadın Türkiye’nin tezleri lehine geliştiğini söylemek yanlış olmayacaktır. Bu uyuşmazlıklardan ilkinde eşit uzaklık prensibinin teamül kuralı niteliği kazanmadığı hükme bağlanmış; ikincisinde ise 1958 Sözleşmesỉnin de aslında kıta sahanlığı sınırlandırmasında hakkaniyeti öncelediği görüşüne, eşit uzaklık-özel durumlar ilkeleri birlikte yorumlanarak ulaşılmıştır. Bu bakımdan, olası bir Ege Denizi üzerinde kıta sahanlığı veya kıta sahanlığı ve münhasır ekonomik bölge sınırlandırılması davasında hakça ilkelerin eşit uzaklık ilkesi lehine geri plana bırakıldığı bir karar çıkması olası görünmemektedir.

Doğal uzantı ilkesinin, özellikle de münhasır ekonomik bölge konseptinin devreye girmesiyle birlikte tek bir sınırlandırma çizgisi talep edilen vakalar açısından geri plana düştüğü ifade edilmelidir. Ancak yine de anakaralar ve adalar arasında, kıta sahanlığının anakaranın bir uzantısı olması dolayısıyla hakkaniyet gerektiren anakara lehine bir sinırlandırmanın talep edilmesi söz konusu olabilir. Bununla birlikte olası bir sınırlandırma kararında hakça ilkelere göre yapılacak düzenlemelerde doğal uzantıya ağıllık verilmesi zayıf bir ihtimal olarak görünmektedir.

Uyuşmazlığı Davası, 2014 tarihli Peru/Şili Deniz Alanları Uyuşmazlığı Davası, Karayip Denizi ve Büyük Okyanus’ta Deniz Alanlarının Sınırlandırılması Davası kararları; Uluslararası Deniz Hukuku Mahkemesi tarafından verilen 2012 tarihli Bengal Körfezi’nde Bangladeş ve Myanmar Arasındaki Deniz Alanlarının Sınırlandırılması Uyuşmazlığı Davası kararı ve yine UDHM Özel Dairesi tarafından verilen 2017 tarihli Gana ve Fildişi Sahili Arasında Atlas Okyanusu’nda Deniz Alanlarının Sınırlandırılması davası kararı; Ek VII Tahkim organları tarafından verilen Bangladeş/Hindistan ve Hırvatistan/Slovenya deniz alanlarının sınırlandırılması uyuşmazlıklarına ilişkin kararlar. Tüm sınırlandırma davalarına ve ilgili mahkemeler ve bu mahkemelerin yaklaşımlarına ilişkin özet niteliğinde bir liste için bkz. Tanaka, Law of the Sea (n 40) 248. 
Yukarıda açıklandığı üzere, Divan’n 2009 tarihli Karadeniz sınırlandırma davasından itibaren kabul ettiği üç aşamalı sınırlandırma metodunun Ege Denizi bakımından da uygulanması olası görünmektedir. Buna göre önce geçici bir eşit uzaklık çizgisi çizilecek, sonra bu çizgi üzerinde hakça ilkelerin gerektirdiği değişiklikler yapılacak ve son aşamada kıyılar ve deniz alanları arasındaki orantısızlık değerlendirilecektir.

Burada en büyük sorun henüz ilk aşamada, eşit uzaklık çizgisinin hangi esas hatlardan itibaren çizileceği meselesinde ortaya çıkmaktadır. Divan’n 2009 tarihli kararında Yılan Adası’nda herhangi bir noktayı eşit uzaklık çizgisinin çizilmesinde esas hat başlangıcı olarak kabul etmediği bilinmektedir. Ancak Ege Denizi’nde sorun daha karmaşıktır. 1982 tarihli Birleşmiş Milletler Deniz Hukuku Sözleşmesi’nin 121/3 hükmüne göre; "İnsanların oturmasına elverişli olmayan veya kendilerine özgü ekonomik bir yaşamı bulunmayan kayalkkların münhasır ekonomik bölgeleri veya kıta sahanlkkları olmayacakttr." 77

Yllan Adası tamamen insan yaşantısından izole bir yer değildir. Dava tarihinde de 100 civarı insan bu ada üzerinde yaşamaktaydı. Ancak buna rağmen Divan, deniz alanlarının sınırlandırılmasında bu adayı dikkate almamış; böylece tarafların deniz alanları arasında ciddi bir orantısızlık meydana gelmesinin önüne geçmiştir.

Şüphesiz Divan’ın bu tespitleri Türkiye’nin tezleri lehinedir. Ancak ifade edildiği üzere Ege Denizi’nde durum daha karmaşıktır zira büyük bir kısmı Türkiye anakarasına yakın olan 3000’e yakın ada bulunmaktadır ve bunların içinde nüfusu otuz binlerden yüz binlere kadar çıkan Sisam, İstanköy, Sakız ve Midilli gibi görece büyük adalar yer almaktadır.

Sonuç olarak Divan’n olası bir Ege Denizi Kıta Sahanlığı uyuşmazlığında üç aşamalı yöntemi uygulaması muhtemeldir ve çizilecek esas hatların nereden başlatılacağı esasen davanın muhtemel sonucunu da ortaya çıaracaktır. Anakaralar yerine adalar ve Türkiye anakarası arasında çizilecek bir eşit uzaklık çizgisi ile Ege Denizi büyük oranda Yunanistan’n kıta sahanlığı içerisinde kalacaktır.

Sınırlandırma hukukuna hâkim olan genel ilkeler şüphesiz Türkiye lehinedir. Öyle ki, sınırlandırmaya esas alınan esas hatlar en doğudaki Yunan adalarından başlatılsa dahi hakça ilkeler ve orantısızlık testi ile birlikte Türkiye lehine eşit uzaklık çizgisinin geriye çekilmesi muhtemel görünmektedir. Bunun da ötesinde, henüz ilk aşamada esas hatların belirlenmesinde nispi bir hakkaniyet kriterinin uygulanması da kaçınılmazdır. Ancak tüm bunlara rağmen sınırlandırmanın yapılmasında anlaşma yoluna gidilmesinin Türkiye’nin lehine olacağı ifade edilmelidir. Zira sınırlandırmaya ilişkin içtihat hukukunda son 25 yılda belirsizlik daha aza indirgenmiş olsa da çıkacak kararın ne olacağı - adalara esas hatların belirlenmesinde ne derece önem verileceği hususundan hareketle - açık bir şekilde görülememektedir. 


\section{ULUSLARARASI ADALET DIVANI KARARLARININ UYGULANMASI}

Ege Denizi Kıta Sahanlı̆̆ı Sorununun Uluslararası Adalet Divanı’na götürülmesi tarafların rızasına bağlı bir konudur. Ancak yargısal yolla çözümün tercih edilmesi durumunda bu tercihin getireceği birtakım sonuçların da farkında olunması gerekmektedir. ${ }^{78}$ Birleşmiş Milletler üyesi olan her devlet taraf olduğu tüm uyuşmazlıklarda, Uluslararası Adalet Divanı kararına uymayı yükümlenir (UAD Statüsü madde 34/1). Bir uyuşmazlığın taraflarından biri, UAD’nın verdiği bir hükme göre kendisine düşen yükümlülükleri yerine getirmezse, öbür taraf BM Güvenlik Konseyi’ne başvurabilir; Konsey de gerekli görürse, hükmün yerine getirilmesi için tavsiyelerde bulunabilir ya da alınacak önlemleri kararlaştırabilir (BM Antlaşması madde 94/2). Divan durumun gerektirdiğine hükmederse, tarafların her birinin haklarını korumak için hangi geçici önlemlerin alınması gerektiğini belirleme yetkisine sahiptir (UAD Statüsü madde 41/1). Öngörülen bu önlemler, kesin karardan önce hemen taraflara ve Güvenlik Konseyi’ne bildirilir (UAD Statüsü madde41/2). Divan'ın kararı ancak uyuşmazlığın tarafları bakımından ve karar verilen dava için bağlayıcıdır (UAD Statüsü madde 59). Hüküm kesindir ve buna karşı başvurma yolu yoktur (UAD Statüsü madde 60). Hükmün anlamı ya da kapsamı üzerinde uyuşmazlık çıkması durumunda, taraflardan herhangi birinin isteği üzerine Divan hükmü yorumlar. Hükmün yenilenmesi isteği ile Divan’a başvurulması ancak, kesin bir etki yapabilecek nitelikte olup hükmün açılanmasından önce Divan'ca ve hükmün yenilenmesini isteyen taraflarca bilinmeyen bir olayın keşfedilmiş olması nedeniyle ve olayın bilinmemesi anılan tarafın kusurundan ileri gelmemişse mümkündür (UAD Statüsü madde 61/1).

BM Güvenlik Konseyi, Uluslararası Adalet Divanı tarafından verilen kararın uygulatılması yönünde karar alabileceği gibi uygulanmasına yönelik önlemlerin alınmasına da karar verebilir. Örneğin kararda kendisine getirilen yükümlülükleri yerine getirmekten kaçınan devlete karşı ekonomik önlemler alınmasına karar verebilir. Siyasal organ olarak Güvenlik Konseyi, UAD’nın kararının içeriğini değiştiremez. UAD Statüsü’nün 60. maddesine göre UAD’nın verdiği bir hüküm kesindir.

Güvenlik Konseyi kararın uygulanmamasının barış ve güvenliği tehdit ettiğini düşünürse VII’nci bölümü işletebilir. VII’nci bölüm haricinde 94/2, 25 ve 103. maddeye dayanarak karar alabilir. BM Antlaşması 39. madde, "Güvenlik Konseyi, barışın tehdit edildiğini, bozulduğunu ya da bir saldırı eylemi olduğunu saptar ve uluslararası barış ve güvenliğin korunması ya da yeniden kurulması için tavsiyelerde bulunur veya 41. ve 42. maddeler uyarınca hangi önlemlerin alınacağını kararlaştırır." demektedir. BM Antlaşması 41'inci maddeye göre, "Güvenlik Konseyi, kararlarını yürütmek için silahlı kuvvet kullanımını içermeyen ne gibi önlemler alınması gerektiğini kararlaştırabilir ve Birleşmiş Milletler üyelerini bu önlemleri uygulamaya çă̆ırabilir. Bu önlemler, ekonomik ilişkilerin ve demiryolu, deniz, hava, posta, telgraf, radyo ve diğer iletişim ve ulaştırma araçlarının tümüyle ya da bir bölümüyle kesintiye uğratılmasını, diplomatik ilişkilerin kesilmesini içerebilir.” BM Antlaşması 42. maddeye göre ise, "Güvenlik Konseyi, 41. maddede öngörülen önlemlerin yetersiz kalacă̆ı ya da kaldiğı kanısına varırsa, uluslararası barış ve güvenliğin korunması ya da yeniden kurulması için, hava, deniz ya da kara kuvvetleri aracılı̆̆ıyla, gerekli saydiğı her türlü girişimde bulunabilir. Bu girişimler gösterileri, ablukayı ve Birleşmiş Milletler üyelerinin hava, deniz ya da kara kuvvetlerince yapılacak başka operasyonları

78 Erkiner, UAD Kararlarının Uygulatılması (n 39) 91-99. 
içerebilir." Güvenlik Konseyi gerekli görürse VII. bölüm haricinde sadece 94. maddeye dayanarak askerî önlemlere karar verebilir. BM Antlaşması 94. maddenin 2. fikrası UAD’nın yargısal kararlarını hedeflemektedir.

Sonuç olarak, Uluslararası Adalet Divanının etkin kılınabilmesi amacıyla BM Antlaşması birtakım tedbirler öngörmüştür. ${ }^{79} \mathrm{BM}$ üyesi her devlet, taraf olduğu tüm uyuşmazlıklarda, UAD kararına uymayı yükümlenir. Bir uyuşmazlığın taraflarından biri, UAD’nın verdiği bir hükme göre kendisine düşen yükümlülükleri yerine getirmezse, öbür taraf BM Güvenlik Konseyi’ne başvurabilir. Konsey de gerekli görürse, hükmün yerine getirilmesi için tavsiyelerde bulunabilir ya da alınacak önlemleri kararlaştırabilir. BM Antlaşması̇nın 94/2 maddesi birçok hususu kapsamaktadır. Bunlardan ilkine göre, lehine karar olan fakat uygulanmayan tarafın başvurusuyla Güvenlik Konseyi meseleye dahil olur. İkinci olarak Güvenlik Konseyi bir karar almak zorunda değildir. Üçüncü olarak Güvenlik Konseyi gereken önlemleri BM Antlaşması VII. bölüme göre ya da doğrudan BM Antlaşması 94. maddeye göre kararlaştırabilir. Dördüncü olarak Güvenlik Konseyi sadece UAD’nın bir kararının uygulanmamasına karşı önlem kararlaştırabilir. Güvenlik Konseyi, UAD’nın kararının içeriğini değiştiremez. UAD Statüsü’nün 60. maddesine göre UAD’nın verdiği bir hüküm kesindir. UAD Statüsü’nün 61'nci maddesine göre Güvenlik Konseyi hükmün yenilenmesini isteyebilir. Daimi üyelerden birinin BM Antlaşması madde 94'e 2 hakkında veto yetkisini kullanıp kullanamayacağı ayrıca cevaplandırılması gereken bir husustur. 27. madde 3. fikrada 94. maddenin 2. fikrası sayılmadığ için veto yetkisinin var olduğunun kabul edilmesi gereklidir ayrıca veto yetkisinin mevcudiyeti ile UAD kararlarının bir daimi üye aleyhine uygulanmasını hukuken olanak dışına çıkarmaktadır. ${ }^{80}$

\section{SONUÇ}

Öncelikle tekraren ifade etmek gerekirse, Türkiye ve Yunanistan arasındaki uyuşmazlıkların sadece kıta sahanlığı meselesinden ibaret olmadığını hatırlatmak gerekir. Halihazırda, Ege Denizi üzerinde karasuları, kıta sahanlığı, henüz ortaya çıkmamış ancak gelecekte muhtemel bir münhasır ekonomik bölge, adaların aidiyeti ve adaların silahsızlandırılması, Doğu Akdeniz üzerinde münhasır ekonomik bölge ve yine dolaylı olarak kıta sahanlığı gibi uyuşmazlık başlıklarından bahsetmek mümkündür.

Türkiye ve Yunanistan arasında var olan deniz alanları sınırlandırmalarının ve özel olarak kıta sahanlığı sınırlandırmasının çözüm yeri olarak Uluslararası Adalet Divanı seçilecek olursa, bu mahkemeden çıkacak kararın kesin olduğu ve dolayısıyla geri dönüşün olmadığı bilinmeli ve meseleye böyle yaklaşılmalıdır.

Uluslararası Adalet Divanı́nın uyuşmazlığa muhtemel yaklaşımı yukarıda mahkemenin içtihadı ışığında açıklanmıştır. Deniz alanlarının sınırlandırılmasına ilişkin uyuşmazlıklarda hakça ilkelere dayanan uygulama zaman içinde 1982 BMDHS’ye de girmiş ve içtihatta da yerleşmiştir. Öte yandan belirsizliklerin giderilmesi adına eşit uzaklık yöntemiyle geçici bir ortay hat çizilmesi ve hakça ilkelere göre bu çizgi üzerinde düzenleme yapılması ve nihayetinde tarafların kıyıları ve deniz alanları

79 Erkiner, UAD Kararlarının Uygulatılması (n 39) 99.

80 Ibid 95. 
arasında bir orantısızlık bulunup bulunmadığı testinin yapılması yargı içtihatlarında güncel olarak kullanılan sınırlandırma yöntemidir. Tüm bu sürecin de yine hakça bir çözümü ortaya çıarması aranmaktadir.

Türkiye 1982 BMDHS’ye taraf değildir. Taraf olsaydı dahi kıta sahanlığı uyuşmazlığını ilgili sözleşmede öngörülen uyuşmazlık çözüm mercilerine havale etmek zorunda olmayacaktı. Aynı şekilde Divan açısından bu uyuşmazlığa ilişkin yargı yetkisi doğuran bir durum da söz konusu değildir. 1978 tarihli Ege Denizi Kıta Sahanlığı Uyuşmazlığı̉nda da bu durum teyit edilmiştir ve o günden bugüne Türkiye’nin Divan’ın bu husustaki yargı yetkisini kabul eden bir girişimi bulunmamaktadır. Sonuç olarak Türkiye istemediği sürece uyuşmazlığa Uluslararası Adalet Divanı’nın veya farklı bir tahkim organının müdahale etmesi söz konusu olmayacaktır.

Uluslararası hukukta uyuşmazlıklar sadece yargı organları eliyle çözümlenmemektedir. 1958 ve 1982 Sözleşmeleri, hem kıta sahanlığı hem de münhasır ekonomik bölge bakımından karşılıklı veya bitişik kıyıları bulunan devletler için öncelikli çözüm yöntemi olarak anlaşmayı göstermektedir. $\mathrm{Bu}$ çalışmanın yazarlarının kanaati de, uyuşmazlığın Divan’a sunulmasının veya başka bir tahkim organına götürülmesinin, hukuki açıdan Türkiye lehine çok ciddi bir biçimde güçlü olan argümanlara rağmen, Türkiye’nin lehine olup olmayacağından emin olunamayacağı şeklindedir. Anılan durumda böyle bir emniyet mekanizması ne uluslararası ilişkiler sistemi ne de uluslararası hukuk düzeni bakımından mevcut değildir. Bu bakımdan uyuşmazlığın ortaya çıktığı günden bugüne kadar olan Türkiye Devleti politikasının aynı şekilde devam ettirilmesinin ve kıta sahanlığı ve bu uyuşmazlıkla ilintili diğer uyuşmazlıkların diplomasi, ikili/karşılıklı görüşmeler ve siyaset alanında çözülmesinin Türkiye’nin ulusal çıkarları bakımından daha isabetli bir yol olacağı kanaatimizce aşikardır.

\section{KAYNAKÇA}

\section{Kitaplar ve Makaleler (Alfabetik):}

Acer Y, 'Ege Kıta Sahanlığı Sorunu ve Uluslararası Yargı Kararları’ iç Aslan Gündüz ve Hüseyin Öztürk (edr) Ege Kıta Sahanlı̆̆ı ve İlişkili Sorunlar Sempozyumu Bildiriler Kitabı (Türk Deniz Araştırmaları Vakfı 2002).

Aksar Y, Teoride ve Uygulamada Uluslararası Hukuk II (3. Baskı, Seçkin 2015).

Aksu F, Türk-Yunan İlişkileri: İlişkilerin Yönelimini Etkileyen Faktörler Üzerine Bir İnceleme (SAEMK Yayınları 2001).

Büyük ME, 'Uluslararası Adalet Divanı - “Wimbledon” Buharlı Gemisi Davası' (2018) 25 Küresel Bakış Çeviri Hukuk Dergisi 35-52.

Büyük ME, Uluslararası Daimi Adalet Divanı - Kararlar, Danışma Görüşleri ve Emirnameler (1922-1930) (Beta 2020).

Büyük ME, Uluslararası Hukukta Hukukun Genel İlkeleri (On İki Levha Yayıncılık 2018).

Caflisch L, 'Maritime Boundaries, Delimitation' in Rudolf Bernhardt (ed.), 11 Encyclopedia of Public International Law (North Holland, Elsevier 1989).

Crawford J, Brownlie's Principles of Public International Law (8th, Oxford University Press 2012).

Erkiner HH, Devletin Haksız Fiilden Kaynaklanan Uluslararası Sorumluluğu (On İki Levha 2010). 
Erkiner HH, 'Devletin Haksız Fiilden Dolayı Uluslararası Sorumluluğunda Uluslararası Hukuk Komisyonu’nun Tespit Ettiği İsnat Kuralları' (2007) 13(3-4) MÜHF-HAD 145-180.

Erkiner HH, 'Birleşmiş Milletler Uluslararası Adalet Divanı Kararlarının Birleşmiş Milletler Güvenlik Konseyi Aracılığıla Uygulatılması’ 2017 23(2) MÜHF-HAD 87-102.

Erkiner HH, 'Uluslararası Topluluk Kavramı’ (2010) 16(1-2) MÜHF-HAD 39-75.

Erkiner HH, 'Uluslararası Topluluk Kavramının Başlıca Görünümleri' (2010) 16(1-2) MÜHF-HAD 77-133.

Evans MD, 'The Law of the Sea' in Malcolm D. Evans (ed), International Law (Oxford University Press 2003).

Gökdemir-Işık N, Kıta Sahanlığı, Hukuki Rejimi ve Ege Sorunu (Doktora Tezi - 9 Eylül Üniversitesi 2006).

Gülçür A, Uluslararası Deniz Hukuku Mahkemesinin Yapısı ve Yargı Yetkisi (On İki Levha Yayıncılık 2017).

Gündüz A, 'Discord Between Greece and Turkey over the Extent of Their Continental Shelves in the Aegean' (1996) 4(2) Hellenic Studies 95-119.

Jaenicke G, 'North Sea Continental Shelf Cases' in Rudolf Bernhardt (ed) 2 Encyclopedia of Public International Law (North Holland, Elsevier 1981).

Kuran S ve Aydın-Okur D, Günel RV, Sarıbeyoğlu M, Uluslararası Hukuk Temel Metinler (3. Baskı, Beta 2014).

Kuran S, Uluslararası Deniz Hukuku (6. Baskı, Beta 2020).

Oellers-Frahm K, 'Aegean Sea Continental Shelf Case' in Rudolf Bernhardt (ed), 2 Encyclopedia of Public International Law (North Holland, Elsevier 1981).

Pazarcı H, Uluslararası Hukuk Dersleri - 2. Kitap (9. Baskı, Turhan Kitabevi 2013).

Shaw MN, Uluslararası Hukuk, (çev.) İbrahim Kaya ve diğerleri, (8th Ed., Türkiye Bilimler Akademisi 2018).

Shaw MN, International Law (8th, Cambridge University Press 2017).

Sohn LB, Cases and Materials on the Law of the Sea (2nd, Brill Nijhoff 2014).

Sur M, Uluslararası Hukukun Esasları (8. Baskı, Beta 2014)

Syrigos A and Thanos D, Atlas of Greek-Turkish Relations (Kathimerini 2020).

Tanaka Y, The International Law of the Sea (Cambridge University Press 2012).

Tanaka Y, Predictability and Flexibility in the Law of Maritime Delimitation (Hart Publishing 2006).

Tekin-Apaydın D, 'Düz Esas Hatların Belirlenmesinde Adaların Rolü: Adalar Saçağı Bilmecesi' (2019) 25(2) MÜHF-HAD 565-589.

Toluner S, Milletlerarası Hukuk Dersleri - Devletin Yetkisi (4. Baskı, Beta 1989).

United Nations Handbook on the Delimitation of Maritime Boundaries (United Nations Publications 2002).

\section{Kararlar (Kronolojik):}

S.S. "Wimbledon", Judgment (Series A No. 1, PCIJ Reports 1923).

Monetary Gold Removed from Rome in 1943 (Preliminary Question), Judgment (ICJ Reports 1954).

North Sea Continental Shelf Cases, Judgment (ICJ Reports 1969).

Delimitation of the Continental Shelf between the United Kingdom of Great Britain and Northern Ireland, and the French Republic (UK, France), 30 June 1977 - 14 March 1978, XVIII Reports of International Arbitral Awards (United Nations 2006).

Aegean Sea Continental Shelf (Greece v. Turkey), Judgment (ICJ Reports 1978).

Case Concerning the Continental Shelf (Tunusia/Libyan Arab Jamahiriya), Judgment (ICJ Reports 1982).

Case Concerning Delimitation of the Maritime Boundary in the Gulf of Maine Area (Canada/United States of America) Judgment (ICJ Reports 1984).

Case Concerning the Continental Shelf (Libyan Arab Jamahiriya/Malta), Judgment (ICJ Reports 1984). 
Affaire de la délimitation de la frontière maritime entre la Guinée et la Guinée-Bissau, 14 Février 1985, XIX Recueil Des Sentences Arbitrales (Nations Unies 2006).

Delimitation of Maritime Areas Between Canada and France, 10 June 1992, XXI Reports of International Arbitral Awards (United Nations 2006).

Maritime Delimitation in the Area between Greenland and Jan Mayen (Denmark v. Norway), Judgment (ICJ Reports 1993).

Eritrea/Yemen - Sovereignty and Maritime Delimitation in the Red Sea (Second Phase), Permanent Court of Arbitration, (17 December 1999), XXII Reports of International Arbitral Awards (United Nations 2006).

Maritime Delimitation and Territorial Questions between Qatar and Bahrain (Qatar v. Bahrain), Judgment, (ICJ Reports 2001).

Land and Maritime Boundary between Cameroon and Nigeria, Judgment (ICJ Reports 2002).

Arbitration between Barbados and the Republic of Trinidad and Tobago, relating to the delimitation of the exclusive economic zone and the continental shelf between them, decision of 11 April 2006, XXVII Reports of International Arbitral Awards (United Nations 2008).

Award in the arbitration regarding the delimitation of the maritime boundary between Guyana and Suriname, 17 September 2007, XXX Reports of International Arbitral Awards (United Nations 2012).

Territorial and Maritime Dispute between Nicaragua and Honduras in the Caribbean Sea, Judgment (ICJ Reports 2007).

Maritime Delimitation in the Black Sea (Romania v. Ukraine), Judgment (ICJ Reports 2009). 